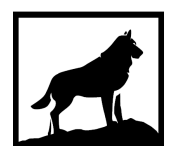

Michigan

Technological

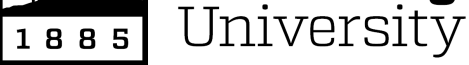

Michigan Technological University

Digital Commons @ Michigan Tech

THE EXTRACTION OF WAXES AND LIPIDS FROM SORGHUM USING GREEN AND RENEWABLE SOLVENTS FOLLOWED BY CONVERSION TO BIOFUELS USING GAMMA-VALEROLACTONE PRETREATMENT

Marissa Gallmeyer

Michigan Technological University, mrgallme@mtu.edu

Copyright 2021 Marissa Gallmeyer

Recommended Citation

Gallmeyer, Marissa, "THE EXTRACTION OF WAXES AND LIPIDS FROM SORGHUM USING GREEN AND RENEWABLE SOLVENTS FOLLOWED BY CONVERSION TO BIOFUELS USING GAMMA-VALEROLACTONE PRETREATMENT", Open Access Master's Thesis, Michigan Technological University, 2021.

https://doi.org/10.37099/mtu.dc.etdr/1246

Follow this and additional works at: https://digitalcommons.mtu.edu/etdr

Part of the Biochemical and Biomolecular Engineering Commons, and the Other Chemical Engineering Commons 


\title{
THE EXTRACTION OF WAXES AND LIPIDS FROM SORGHUM USING GREEN AND RENEWABLE SOLVENTS FOLLOWED BY CONVERSION TO BIOFUELS USING GAMMA-VALEROLACTONE PRETREATMENT
}

\author{
By \\ Marissa R. Gallmeyer
}

\begin{abstract}
A THESIS
Submitted in partial fulfillment of the requirements for the degree of

MASTER OF SCIENCE

In Chemical Engineering

MICHIGAN TECHNOLOGICAL UNIVERSITY

2021
\end{abstract}

(C) 2021 Marissa R. Gallmeyer 
This thesis has been approved in partial fulfillment of the requirements for the Degree of MASTER OF SCIENCE in Chemical Engineering.

Department of Chemical Engineering

Thesis Advisor: Dr. Rebecca Ong

Committee Member: $\quad$ Dr. David Shonnard

Committee Member: $\quad$ Dr. Judith Perlinger

Department Chair: Dr. Pradeep Agrawal 


\section{Table of Contents}

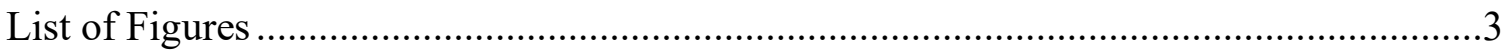

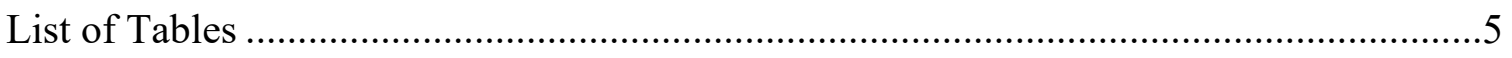

Preface

Acknowledgements ...............................................................................................

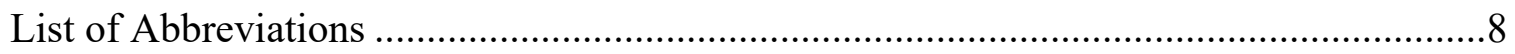

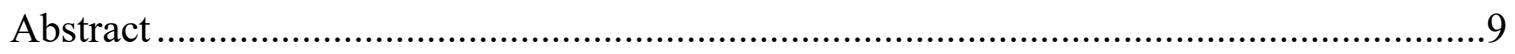

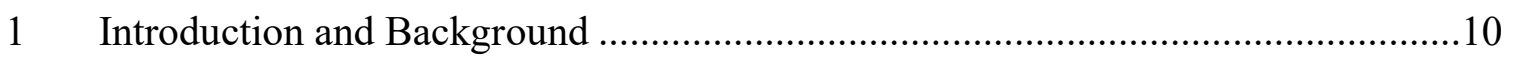

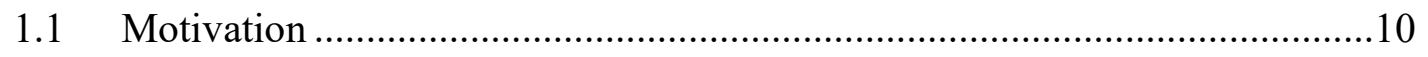

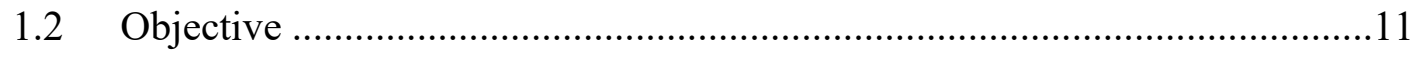

1.3 Sorghum Structure and Composition .........................................................11

1.3.1 Lignocellulosic Biomass Structure .................................................12

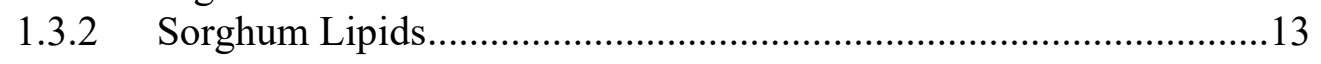

1.4 Green Organic Solvents for Lipid Extraction...............................................15

1.4.1 $\gamma$-Valerolactone ............................................................................16

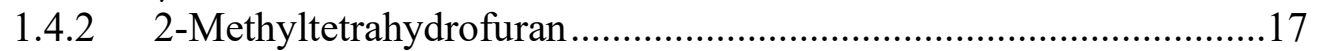

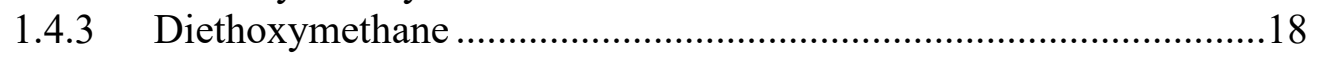

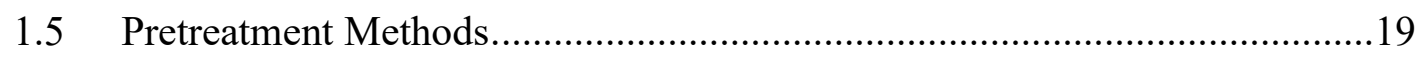

1.5.1 GVL Pretreatment Method .............................................................20

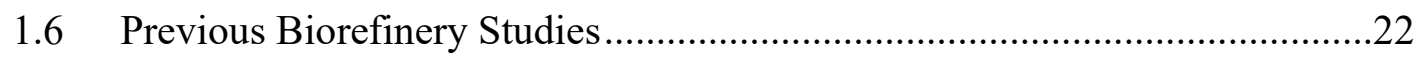

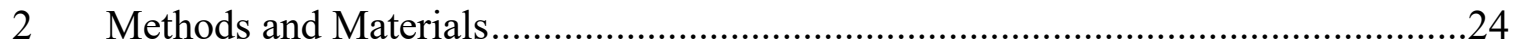

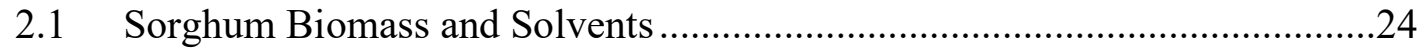

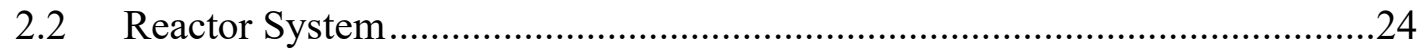

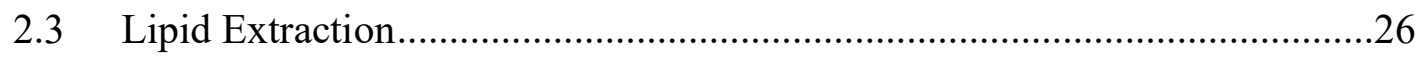

2.4 Solvent Evaporation and Lipid Collection and Analysis ...............................27

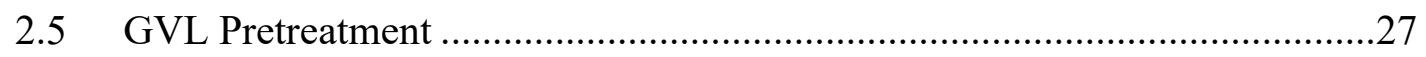

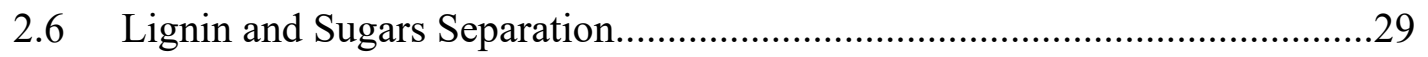

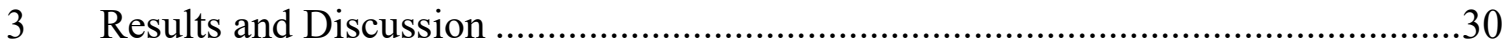

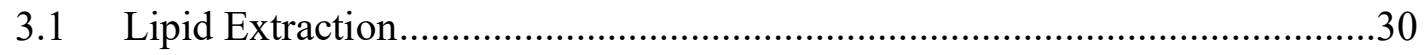

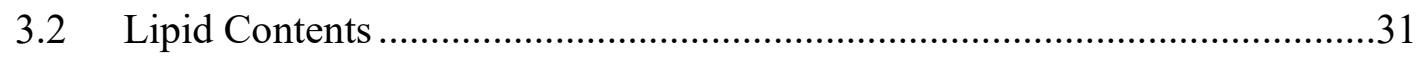




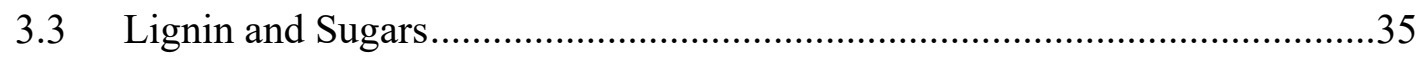

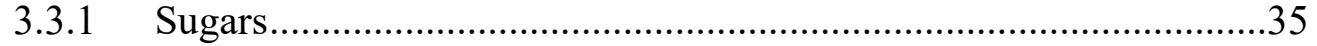

3.3.2 Sugar Degradation Compounds ...............................................36

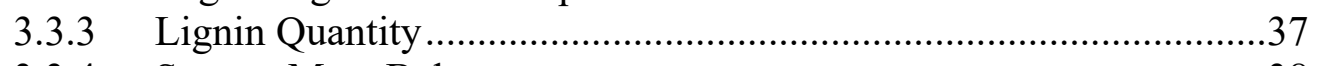

3.3.4 System Mass Balance .............................................................. 38

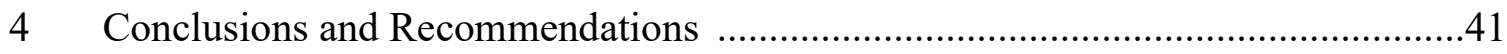

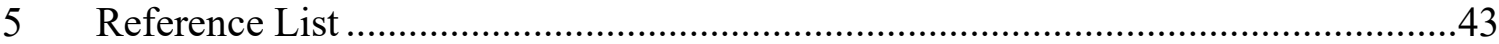




\section{List of Figures}

Figure 1.1. The sorghum cell wall consists mainly of cellulose, hemicellulose and lignin, and the goal of pretreatment is to significantly disrupt the cell wall components to allow enzyme access. Created with Biorender.

Figure 1.2. Chemical structure of 1) hexane, 2) 2-methyltetrahydrofuran, 3) yvalerolactone, and 4) diethoxymethane.

Figure 1.3. GVL can be produced form cellulose and hemicellulose through a series of reactions. Reproduced from ${ }^{28}$

Figure 1.4. Visual representation of MeTHF production through both furfural and GVL pathways. Reproduced from ${ }^{26,32}$.

Figure $1.5 \mathrm{GVL}$ pretreatment is carried out between $120{ }^{\circ} \mathrm{C}$ and $226^{\circ} \mathrm{C}$. When mixed with toluene for separation, the solution is bi-phasic at low temperatures and mono-phasic at high temperatures. Based on ${ }^{6}$

Figure 2.1 Photograph of reactor system with key components labeled.

Figure 2.2. Reactor system used for extractions. Solvent flows from the reservoir through the desired reactors and into the appropriate collection and storage vessel. Backpressure applied using the gas lines in blue...........................................26

Figure 2.3 GVL pretreatment following extraction consists of three stages with three separate solvents used and three products collected.

Figure 3.1 Quantity of sorghum extractives recovered using a) hexane, b) DEM, and c) MeTHF with average values indicated for comparison.

Figure 3.2 Representative chromatograms of lipids collected across all temperatures from a) hexane, b) MeTHF, c) DEM extractions with wax region indication across all graphs.

Figure 3.3 Chromatogram heat map of lipids collected across all temperatures from a) hexane, b) MeTHF, c) DEM extractions where red indicates most overlap between the different chromatograms and violet the most unique peak regions...34

Figure 3.4 GVL pretreatment sugar products yield of total starting sorghum sugar content $^{48}$ for each extraction solvent used

Figure 3.5 Quantity of lignin collected from Stage 1 and Stage 2 of GVL pretreatment preceded by each solvent extraction. The error bars represent the standard deviation from three replicates. 
Figure 3.6 The dried lignin from a) hexane, b) MeTHF, c) DEM extracted biomass is slightly different colored, even when dry. The colors are not as obvious as those

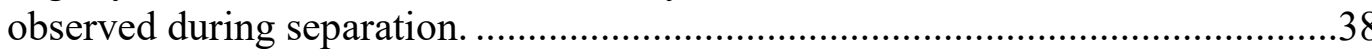

Figure 3.7 Example mass balance of primary products flow chart for DEM sample........39 


\section{List of Tables}

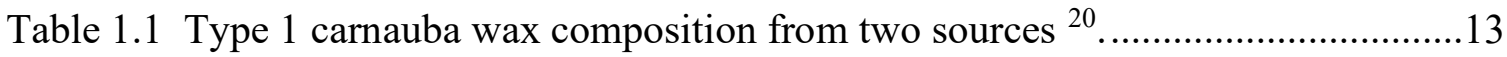

Table 1.2 Comparison of carnauba and sorghum wax chemical composition ${ }^{18}$..............14

Table 1.3. Summary of various methods of pretreatment of lignocellulosic biomass. Adapted from ${ }^{37,38}$

Table 3.1 Compounds detected in chromatograms for hexane, MeTHF, and DEM with length of carbon chains and desired wax compounds bolded.

Table 3.2 Observed physical characteristics of the lignin obtained from pretreatment after lipid extractions. Observations were made during the separation process.

Table 3.3 Lipid extraction and pretreatment mass balance averages with standard deviation for each extraction solvent. *Data unavailable; average based on two samples instead of three. **Data unavailable for two of the samples?; assumed that all three samples had the same unreacted biomass fraction. 


\section{Preface}

Rebecca Ong and John Mullet led, designed, and coordinated the overall project. Rebecca Ong designed the reactor system and Jerry Norkol constructed the apparatus. Marissa Gallmeyer operated the system and performed extractions and GVL pretreatment experiments. Robert Chemelewski performed the GC-MS analysis of lipids. Mcsean Mcgee performed analysis on the sugars from pretreatment. Marissa Gallmeyer wrote the manuscript with input from other authors. Rebecca Ong edited the manuscript.

This material is based upon work supported in part by the Great Lakes Bioenergy

Research Center, U.S. Department of Energy, Office of Science, Office of Biological and Environmental Research under Award Number DE-SC0018409. 


\section{Acknowledgements}

I would like to thank my advisor, Dr. Ong for all of her help and support throughout my time as an undergraduate and graduate researcher at Michigan Tech. I would not be where I am today without all of the opportunities I have had in this lab. I an incredibly grateful for the chance to work on this project and for all that she taught me over the years.

I also want to extend a huge thank you to Sarvada Chipkar for her help and mentorship over the past three years. She was always there to help me fix equipment, answer questions, and offer advice. Every time I have asked for help, she has never hesitated and always come to work with a smile. I would also like to thank all of the other members of the Ong lab for being fantastic lab mates and making feel welcome for teaching me so much.

The Chemical Engineering department at Michigan Tech also deserves my gratitude for the amazing people and opportunities it has introduced me to. There have been countless students, faculty, and staff who have helped me throughout my degree and deserve my thanks. Each one of them has always been willing to offer advice and expertise whenever I have needed it.

I would like to extend my thanks to my parents, Robin and Cecilia Gallmeyer, and my sisters, Malina and Mahana Gallmeyer, for their constant love and support. My parents have always been there and supported my academic endeavors and supplied with me many gift coffee gift cards to get through my degree. My sisters have always been an encouragement, constantly providing optimism and puns to brighten my day.

I especially need to thank Ben Wiegand who has been there whenever I struggled and has always provided love, support, and logical advice when obstacles occur. He has also pushed me to take breaks and take care of myself so that I can perform my best academically and personally. I would not be where I am today without the many dinners, conversations, and adventures we have had. 


\title{
List of Abbreviations
}

\author{
GVL $-\gamma$-Valerolactone \\ MeTHF - 2-methyltetrahydrofuran \\ DEM - Diethoxymethane \\ GC-MS - Gas Chromatography - Mass Spectrometry \\ GLBRC - Great Lake Bioenergy Research Center \\ ID - Inner Diameter \\ 5-HMF - 5-hydroxymethylfurfural \\ LA - Levulinic acid
}




\section{Abstract}

Plant matter contains waxes and lipids that can be extracted and used or sold as a valueadded product prior to conversion of the remaining plant material to biofuels. Wax and lipid extraction of plant materials is currently performed using volatile, non-renewable hydrocarbons, primarily hexane, which is produced from fossil fuels and can pose a health and safety hazard. The purpose of this study is to compare the amount and characteristics of waxes extracted by hexane with those extracted using organic solvents that are less toxic and can be produced from renewable sources.

Sorghum samples were extracted separately with hexane, 2-methyltetrahydrofuran (MeTHF), and diethoxymethane (DEM). Each solvent was used to conduct extractions at $25^{\circ} \mathrm{C}, 40{ }^{\circ} \mathrm{C}, 60{ }^{\circ} \mathrm{C}$, and $80{ }^{\circ} \mathrm{C}$. The amount of wax extracted was determined and samples analyzed using GC-MS. The extractions using MeTHF produced the most lipids, followed by DEM, and then hexane. However, the lipids extracted using hexane contained desired waxes that were not found in the extracts of the other solvents. Therefore, hexane can be used to produce the highest quality waxes via extraction from sorghum. None of the solvents produced pure waxes and would require further purification.

Following extraction, the biomass was fractionated using a $\gamma$-valerolactone (GVL) pretreatment. The quantity of the lignin obtained as well as the quality of the sugars was analyzed. The amounts of lignin collected varied based on the extraction solvent, with biomass extracted using DEM producing the most, followed by MeTHF, and hexane. 


\section{Introduction and Background}

\subsection{Motivation}

Today, the global population consumes more energy than ever before, and this is only expected to grow as the population increases and as the world becomes further industrialized ${ }^{1}$. Fossil fuels combustion make up $86 \%$ of energy production currently, and this demand will increase exponentially in the future ${ }^{2}$. However, not only are fossil fuels non-renewable, but their combustion and subsequent production of carbon dioxide contribute to global warming and worldwide changes in climate ${ }^{3}$. It is estimated that fossil fuels are the cause for $73 \%$ of global $\mathrm{CO}_{2}$ emissions ${ }^{4}$. Therefore, the development of sustainable alternatives to petroleum and other fossil fuels is an urgent challenge that scientists are currently facing.

One alternative energy source is biomass, which can be converted into biofuels. The biomass is produced from biological materials that have been freshly grown, often for the specific purpose of making biofuels ${ }^{1}$. While there are several forms of biomass suitable for conversion to biofuels, the cost to grow most kinds of biomass and produce the fuel is significantly larger than that of petroleum fuels ${ }^{5}$. This cost disparity contributes to the slow growth in the use of biofuels compared to fossil fuels.

Converting grain or sugar crops is easier and less costly than producing fuel from lignocellulosic biomass. However, grains and sugar crops are also utilized in food production, which can cause an economic competition between food and fuel, increasing the cost of either food or bioethanol ${ }^{1}$. The use of these crops can also result in leftover portions of the plants, including husks and stems, being burned in large quantities, polluting the environment ${ }^{1,5}$. However, the use of lignocellulosic biomass to produce bioethanol can reduce these issues. Lignocellulosic biomass can be grown on marginal land with minimal resources and does not have to compete with food production ${ }^{6}$. Lignocellulose is also the most sustainable and renewable biomass due to the potential to produce large quantities and ease with which it can be grown ${ }^{1}$. Lignocellulose also includes the excess husks, leaves, and stems from food production, and these materials could be converted to fuels and reduce the amount of plant waste from crops such as corn and sugarcane ${ }^{5}$.

While the production of bioethanol from lignocellulosic biomass is more costly, there are additional methods to accomplish this goal while increasing the environmental and economic sustainability of the process. These methods include obtaining additional value-added intermediate products that can either be sold or further utilized in the process, such as organic solvents, fuels, biochar, pharmaceuticals, waxes, and polymers ${ }^{6-}$ ${ }^{8}$. Since sorghum contains waxes that are similar to those commonly used in many consumer products, there is an opportunity to extract them using organic solvents ${ }^{9}$. The waxes can then be sold as a separate product, increasing the economic sustainability of the bioethanol production process. Hexane is commonly used for lipid extractions but is 
produced from petroleum and is therefore a non-renewable solvent ${ }^{10}$. Because of this, alternative, green solvents should be considered. In this study, 2-methyltetrahydrofuran (MeTHF) and diethoxymethane (DEM) were considered as potential green solvents for the extraction process. After the extraction, a $\gamma$-valerolactone (GVL) pretreatment was utilized to break down the plant matter. This has multiple benefits as GVL can be a byproduct of lignocellulosic bioethanol production and can be used in a pretreatment method that is more cost effective than others ${ }^{6,11}$. It is possible that this combination of extraction and GVL pretreatment will contribute to a more economically and environmentally sustainable process. This may help to make the production of bioethanol more favorable for industrial use and therefore reduce the required amount of fossil fuels. It is for these reasons that biomass sorghum with a (GVL) pretreatment has been chosen for these experiments.

\subsection{Objective}

The primary goal of this experiment was to determine the amount and composition of lipids extracted from energy sorghum using green solvents and to verify if these extractions can be used to obtain quality waxes, such as those typically removed from sorghum using hexane. The second objective was to determine if the process impacts the subsequent GVL pretreatment efficacy. This was achieved by performing a series of extractions at varying temperatures with either hexane, 2-methyltetrahydrofuran, or diethoxymethane. The waxes were collected, and the quality analyzed using GC-MS. Following the extractions, GVL pretreatment was performed on the biomass. The resulting lignin and sugars were analyzed to determine the quantity and the quality of the product.

\subsection{Sorghum Structure and Composition}

Sorghum is a lignocellulosic crop that is traditionally grown in arid climates in Africa, Asia, Australia, Central America, and the United States. In the United States, sorghum is primarily grown and used for ethanol production ${ }^{9}$. There are several different forms of sorghum including grain sorghum, sweet sorghum, and biomass sorghum ${ }^{12}$. Sweet sorghum contains more sugars in the stem that can be extracted and fermented while biomass sorghum has more cellulosic fibers ${ }^{12}$. However, sweet sorghum is often used for human consumption and is considered a first-generation biofuel crop, like corn. Biomass sorghum, an annual crop, is considered a second-generation biofuel crop as it is grown to produce lignocellulosic biomass and cannot be used as a food ${ }^{13,14}$. Biomass sorghum is notable for its rapid growth rate, producing high biomass yields in 90-100 days, as well as its resistance to drought ${ }^{12}$. It also has a low lignin content and a high cellulose and 
hemicellulose content when compared to other lignocellulosic biomass feedstocks, making it favorable for the generation of bioethanol ${ }^{13}$.

\subsubsection{Lignocellulosic Biomass Structure}

Sorghum, like all lignocellulosic biomass is composed of three main cell wall polymers, cellulose, hemicellulose, and lignin ${ }^{1}$. Biomass sorghum is $14 \%$ lignin, $29 \%$ glucan, and $16 \%$ xylan, on average. The remainder of the plant consists of ash, protein, sucrose, starch, and other extractable components ${ }^{15}$. Cellulose forms the basic structure of the cell wall. It is a homopolysaccharide consisting only of glucose molecules ${ }^{1}$. The number of glucose units in the polymer vary greatly but is usually greater than $1000{ }^{1}$. These units are linked together by $\beta$-(1,4)-glycosidic bonds in repeating units of 2 glucose molecules, called cellobiose. The hydrogen bonding between the cellulose chains causes them to form parallel chains (Figure 1.1) ${ }^{1}$. These parallel chains can form dense regions that are difficult to access during saccharification and must be more accessible to enzymes used in the process ${ }^{1}$.

The hemicelluloses are a class of compounds that provide physical strength to cell walls and can be composed of pentoses (xylose and arabinose), hexoses (glucose, mannose, and galactose), uronic acids and acetyl side groups ${ }^{1,15}$. The content and amounts of the different types of hemicellulose can vary greatly across species ${ }^{1}$. In grasses, such as sorghum, the main hemicellulose is glucuronoarabinoxylan, which consist of a xylose backbone with arabinan and glucuronic acid side-chains ${ }^{1}$. Like cellulose, the sugar monomers are held together with $\beta$ - $(1,4)$-glycosidic bonds or with $\beta$ - $(1,3)$-glycosidic bonds. However, unlike cellulose, hemicellulose can sometimes be a branched heteropolymer and has a lower molecular weight ${ }^{1,13}$. The chain lengths are generally shorter than cellulose, usually only 100-200 molecules long. These molecules are much more amorphous than cellulose and not difficult to break down during hydrolysis provided the correct enzymes are used, unlike the more rigid cellulose molecules.

Lignin, the third major polymer in lignocellulose, is a more complex molecule that provides structural support and enables the plant to resist bending and compression ${ }^{1}$. It is an amorphous heteropolymer that contains many aromatic molecules. Coniferyl alcohol, p-coumaryl alcohol, and sinapyl alcohol are the three main monomers that make up the lignin polymer through alkyl or aryl-ether linkages When incorporated into the lignin polymer, sinapyl and $p$-coumaryl alcohol are referred to as syingyl and $p$-hydroxyphenyl units, respectively, and are found in many grasses ${ }^{1,16}$. Lignin is resistant to many biological attacks and covers much of the cellulose, making it difficult for enzymes to access the polysaccharides during enzymatic hydrolysis. Therefore, it is imperative that the lignin be broken down so that it does not restrict access to cellulose or hemicellulose 1 . 


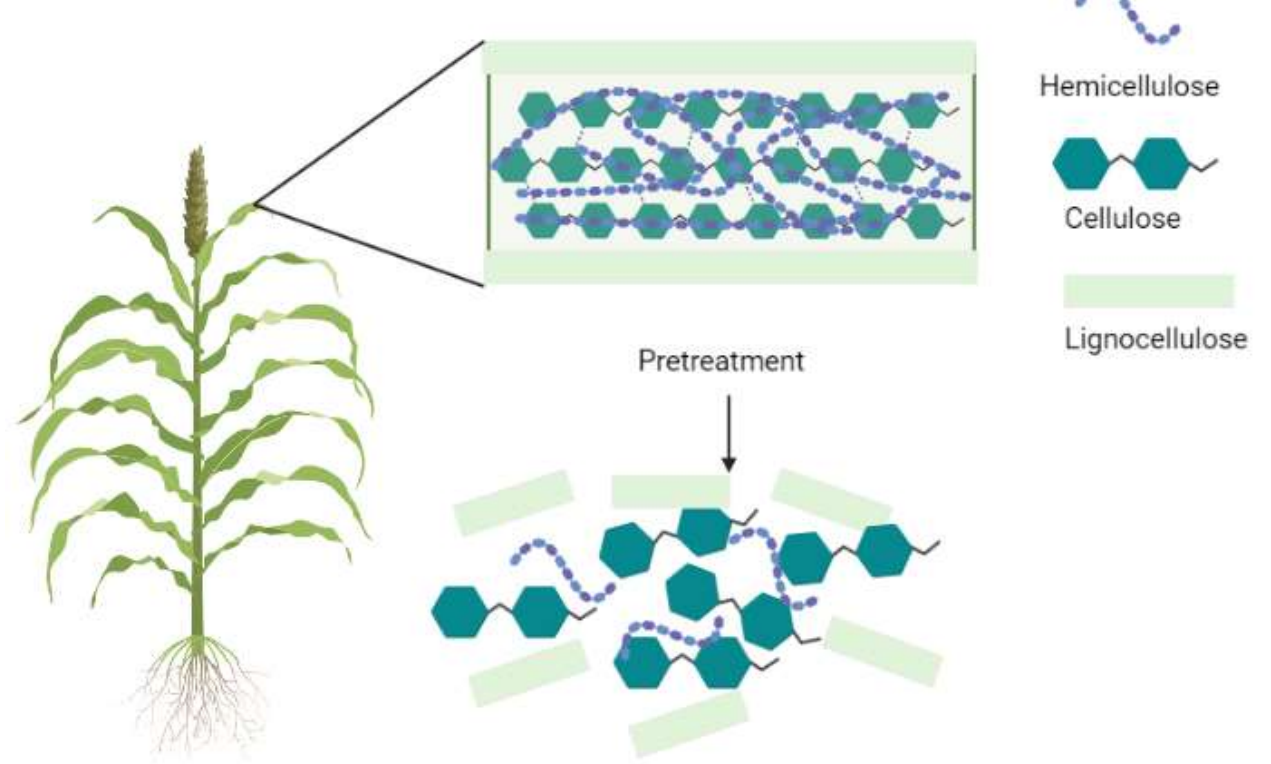

Figure 1.1. The sorghum cell wall consists mainly of cellulose, hemicellulose and lignin, and the goal of pretreatment is to significantly disrupt the cell wall components to allow enzyme access. Created with Biorender.

\subsubsection{Sorghum Lipids}

Sorghum kernels typically have the thickest wax layer, but similar waxes have been found in the thin layers that cover the aboveground part of the plant ${ }^{17}$. It has been found that that grain sorghum kernels contain waxes with properties similar to those found in carnauba wax ${ }^{9,18}$. Carnauba wax can be obtained from the leaves of Copernicia prunifera tree that is grown exclusively in Brazil ${ }^{19}$. For most countries, this means that it must be imported before it can be used in products including cosmetics, polishes, food products, and as coatings in the paper industry ${ }^{9}$. Carnauba wax has a melting point of $82-85{ }^{\circ} \mathrm{C}$ and is typically used to increase the melting points of other waxes ${ }^{18}$.

Carnauba waxes are classified into three types, olho wax, fatty wax, and sandy wax. The olho wax is the crude wax extracted from the plant is a yellow color and is the type that will be compared to the waxes extracted from the sorghum ${ }^{20}$. The waxes are composed of approximately $80 \%$ esters and a combination of other compounds including free alcohols, aliphatic acids, aromatic acids, $\omega$-hydroxycarboxylic free acids, hydrocarbons (paraffins) and triterpene diols ${ }^{20}$.

Table 1.1 Type 1 carnauba wax composition from two sources ${ }^{20}$.

\begin{tabular}{lll}
\hline Constituent & Amount (\%) & Amount (\%) \\
\hline Aliphatic Esters & 40 & $38-40$ \\
\hline
\end{tabular}




\begin{tabular}{lll}
\hline $\begin{array}{l}\text { Diesters of 4- } \\
\text { hydroxycinnamic acid }\end{array}$ & 21 & $20-23$ \\
\hline $\begin{array}{l}\text { Esters of } \omega \text {-hydroxycinnamic } \\
\text { acid }\end{array}$ & 13 & $12-14$ \\
\hline Free alcohols & 12 & $10-12$ \\
\hline $\begin{array}{l}\text { Diesters of 4- } \\
\text { methoxycinnamic acid }\end{array}$ & 7 & $5-7$ \\
\hline Free aliphatic acids & 4 & - \\
\hline Free aromatic acids & 1 & - \\
\hline Hydrocarbons (paraffins) & 1 & $0.3-1$ \\
\hline $\begin{array}{l}\text { Free } \omega \text {-hydroxycarboxylic } \\
\text { acids }\end{array}$ & 0.5 & - \\
\hline Triterpene diols & 0.5 & 0.4 \\
\hline $\begin{array}{l}\text { Aromatic compounds and/or } \\
\text { resins }\end{array}$ & 4.4 & - \\
\hline $\begin{array}{l}\text { Free acids and other } \\
\text { unknown constituents }\end{array}$ & - & $5-7$ \\
\hline Reference & 21 & 22 \\
\hline
\end{tabular}

Sorghum contains a large amount of waxes and lipids, making it the ideal biomass to consider for an extraction in an integrated biorefinery, as discussed in Nigheim et al ${ }^{23}$. Additionally, sorghum waxes have been observed to behave somewhat similarly to carnauba waxes ${ }^{18}$. However, the exact chemistry has been difficult to ascertain. There have been multiple compositions of sorghum wax reported with the most common composition reported in Table 1.2. However, other groups have reported fewer alcohols and the existence of fatty acids, lipids, or aldehydes ${ }^{18}$. The exact values have varied between research groups ${ }^{18}$. It has been theorized that if the amount of alcohols was reduced, which can be done through elution, the properties could be closer to those of carnauba waxes ${ }^{24}$.

Table 1.2 Comparison of carnauba and sorghum wax chemical composition ${ }^{18}$

\begin{tabular}{lll} 
& Carnauba & Sorghum \\
\hline Wax and other Esters & $85 \%$ & $46-50 \%$ \\
\hline Fatty Alcohols & $2-3 \%$ & $40-46 \%$ \\
Hydrocarbons & $1.5-3 \%$ & $4-5 \%$ \\
\hline Free Fatty Acids & $3-3.5 \%$ & - \\
\hline
\end{tabular}


Lactides

Resins

Unknown Lipids
$2-3 \%$

$4-6 \%$

$-$

$0-8 \%$

\subsection{Green Organic Solvents for Lipid Extraction}

Hexane is a commonly used solvent for the extraction of lipids due to its low boiling point $\left(69^{\circ} \mathrm{C}\right)$, non-polarity, and chemical stability. While useful, hexane is produced from petroleum, a non-renewable resource and is considered hazardous ${ }^{10}$. It is regulated under the Clean Air Act by the Environmental Protection Agency since it evaporates easily and is only slightly soluble in water ${ }^{10}$. Therefore, a greener alternative would be favorable as opposed to hexane. Green chemistry is the implementation of chemical products and processes that remove or reduce the use or generation of hazardous substances ${ }^{25}$. It should be noted that the use of the word hazardous here includes the concepts of risk reduction and pollution prevention ${ }^{25}$. The use of environmentally friendly solvents is important to consider since solvents are the largest source of waste in chemical processes and should therefore be chosen with care ${ }^{26}$. Since avoiding solvents completely is not practical, "green solvents" that are also produced from renewable sources are ideal.

An ideal green wax extraction solvent would have low flammability and toxicity, be liquid at ambient and process conditions, and be easy to separate from the desired product. Solvents with a high boiling point can be challenging to separate from the lipid product via evaporation or distillation. Initially d-limonene was considered, but due its high boiling point and corrosivity it was very difficult to extract and recover the lipids and was removed as a solvent option. However, if solvents are gaseous at ambient conditions, more complex and expensive equipment is necessary to perform the extraction and product collection. Therefore, solvents with very low boiling points are also unfavorable. These ideas were considered when choosing $\gamma$-valerolactone (GVL) for pretreatment, and 2-methyltetrahydrofuran (MeTHF) and diethoxymethane (DEM) as green solvents for the lipid extractions or pretreatment process (Figure 1.2). 
1

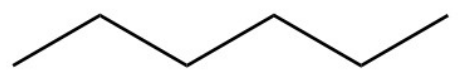

3

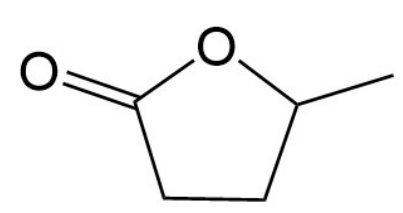

2

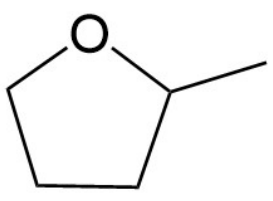

4

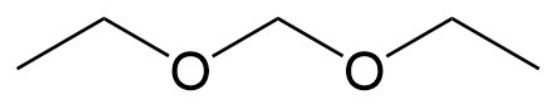

Figure 1.2. Chemical structure of 1) hexane, 2) 2-methyltetrahydrofuran, 3) $\mathrm{y}$-valerolactone, and 4) diethoxymethane.

\subsubsection{Y-Valerolactone}

Gamma-valerolactone (GVL) is cyclic ester that consists of 4 carbon atoms and one oxygen atom in the ring (Figure 1.2) [23]. GVL is liquid at standard conditions and has a high boiling point of $207^{\circ} \mathrm{C}$. While GVL has low toxicity, it is still considered flammable, though the low volatility of the liquid means that the risk at normal conditions is low. However, because of its high boiling point, it is difficult to separate from other organic materials, making it a poor choice for a lipid extraction solvent. GVL can be produced from intermediate chemicals from both the cellulose and hemicellulose fractions of lignocellulosic biomass ${ }^{28}$ (Figure 1.3). The cellulose fraction can be degraded to glucose and then to fructose with the use of an acid catalyst. This can then be dehydrated to produce 5-hydroxymethylfurfural and rehydrated to produce levulinic acid ${ }^{29}$. Levulinic acid can be selectively reduced using various catalytic systems to produce GVL $^{28}$.

To produce GVL from hemicellulose the hemicellulose must first be degraded to xylose and then to furfural. Furfural is then converted to furfuryl alcohol via catalytic hydrogenation. Once furfuryl alcohol is obtained, it can be hydrolyzed to produce levulinic acid, which can be used as previously described ${ }^{28}$. GVL has been shown to be effective as pretreatment method, which is described in detail in a later section. 


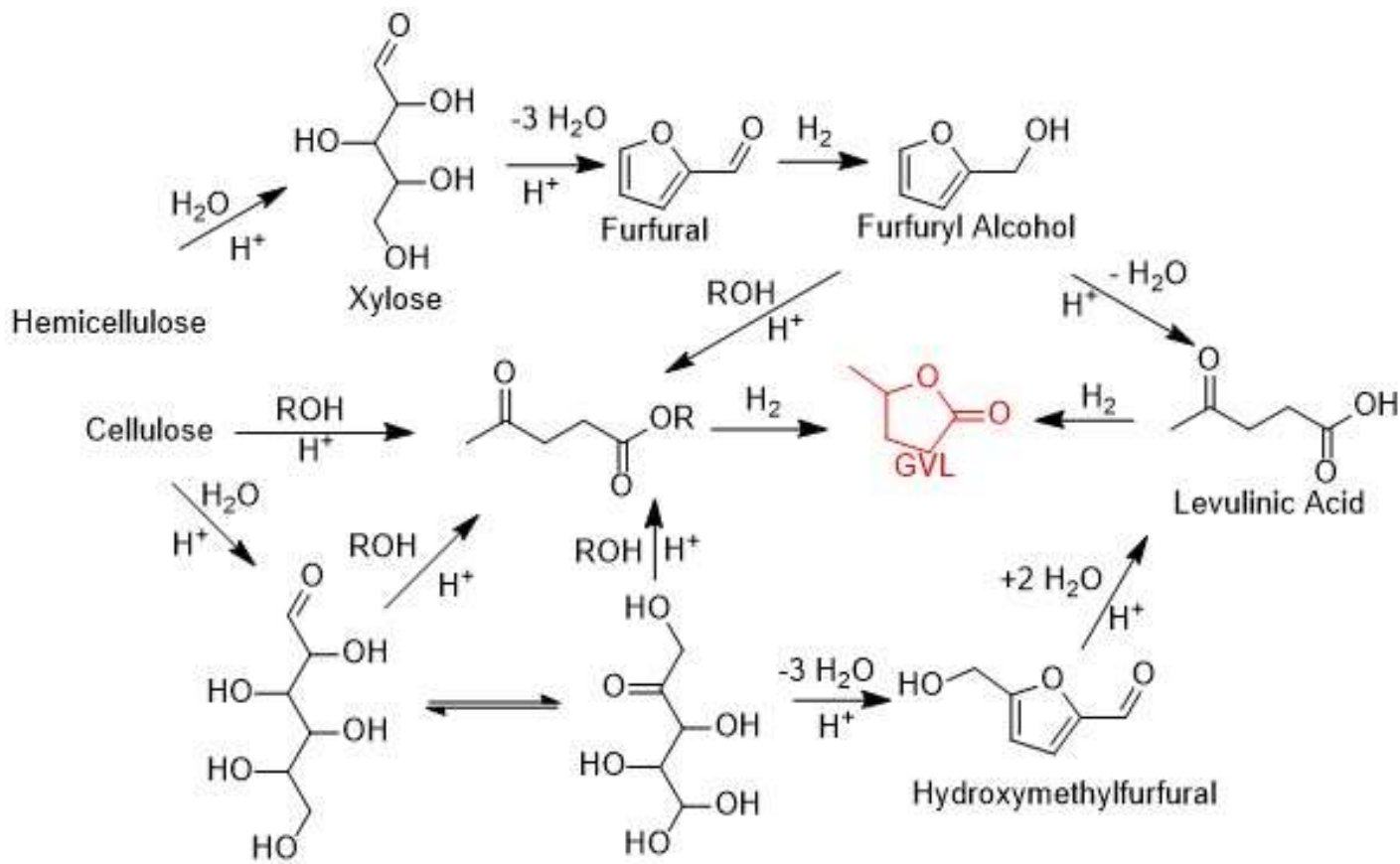

Glucose

Fructose

Figure 1.3. GVL can be produced form cellulose and hemicellulose through a series of reactions. Reproduced from ${ }^{28}$

\subsubsection{2-Methyltetrahydrofuran}

2-Methyltetrahydrofuran (MeTHF) has a similar structure to GVL, but does not have the double bonded oxygen on the carbon atom opposite the methyl group and has a boiling point of $80^{\circ} \mathrm{C}$ (Figure 1.2) ${ }^{30}$. This boiling point is slightly higher than that of hexane but is still low enough that it can be easily evaporated after use. It is very similar in structure to tetrahydrofuran (THF), a non-renewable solvent that has also been used in lipid extractions ${ }^{31}$.

There are multiple methods that can be used to produce MeTHF. Similar to GVL, it can be produced from furfural and levulinic acid and can therefore be produced from lignocellulosic biomass ${ }^{26,30}$ (Figure 1.4). To produce MeTHF from furfural, a two-step process is used. This consists of first forming 2-methylfuran and then hydrogenating the 2-methylyfuran into MeTHF ${ }^{30}$. The process to convert levulinic acid to MeTHF begins with the previously described process for producing GVL. GVL can be hydrogenated to a cyclic hemiacetal that is in equilibrium with the open hydroxyaldehyde. The open form can be hydrogenated to 1,4-pentanediol. Acid-catalyzed dehydration leads to cyclization of the diol by etherification to give 2-MeTHF ${ }^{26}$. 
MeTHF is considered noncarcinogenic, noncorrosive, and is less environmentally damaging than hexane ${ }^{32}$. It has been tested as a substitute in the extraction of carotenoids in place of hexane and had a higher yield, indicating that it has potential to replace hexane in other solvent uses ${ }^{32}$. One such example of this is in its use to extract lipids from algae for conversion to biodiesel. It has been shown that MeTHF nearly three times the lipids from dried algae than hexane in a single solvent extraction at room temperature ${ }^{33}$. Because of this, it is an ideal green solvent to use in the extraction of waxes and lipids from sorghum.

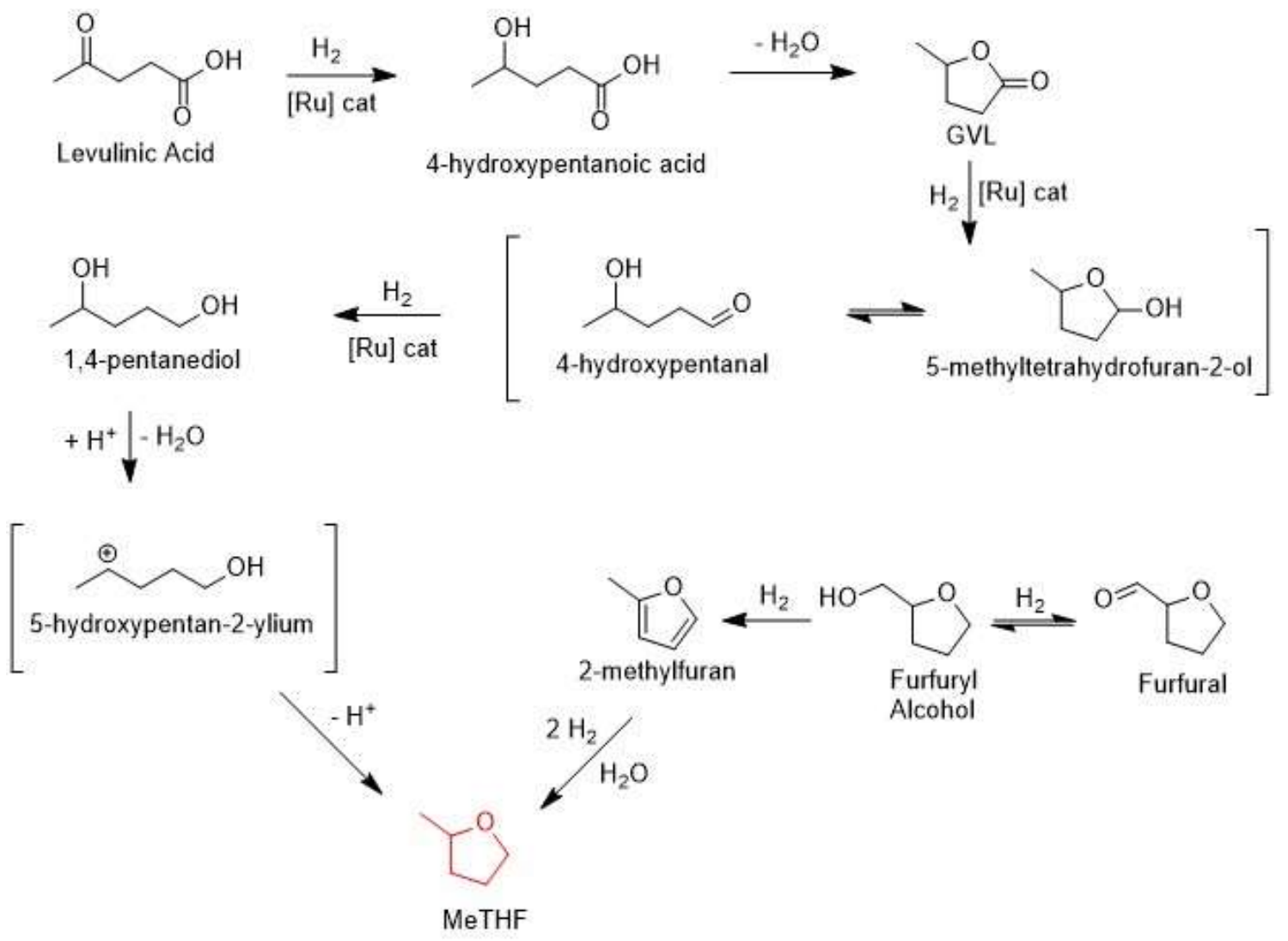

Figure 1.4. Visual representation of MeTHF production through both furfural and GVL pathways. Reproduced from ${ }^{26,32}$.

\subsubsection{Diethoxymethane}

Diethoxymethane (DEM) consists of an acetal group framed by two ethyl groups and has a boiling point of $88^{\circ} \mathrm{C}$, making it liquid at ambient conditions, but volatile enough to evaporated with relative ease ${ }^{34}$. It also has a different chemical structure than MeTHF, allowing a wider variety of molecular formations to be tested. The simplest way to produce DEM is by reaction of formaldehyde with ethanol over a catalyst ${ }^{34}$. There are different ways to produce formaldehyde including chemical conversion of methane, biomass burning, fossil fuel combustion, natural gas flaring, ethanol refining, and 
possibly in vegetation or agricultural activity ${ }^{35}$. Though it is not always produced from a renewable source, it can be, making DEM a potentially green and renewable solvent. DEM is not water soluble, which makes its recovery simpler than other solvents and is considered a non-hazardous air pollutant, resulting in it being considered safe for industrial use ${ }^{34,36}$.

DEM has been used in the extraction of oils containing fatty acids from sunflower seeds and compared to hexane and tetrahydrofuran, another nonrenewable solvent. It was found that DEM extracted a 3\% greater weight of oil and had a higher overall extraction rate and a $28.6 \%$ free fatty acid content ${ }^{31}$. This finding demonstrates that it has similar solvent behavior to hexane and tetrahydrofuran. Because of its ability to extract lipids at a higher rate than both nonrenewable solvents and is a greener alternative, it has been considered as a solvent for extracting waxes and lipids from sorghum.

\subsection{Pretreatment Methods}

The purpose of pretreatment methods is to break down the structure lignocellulose in biomass so that the sugars can be accessed for conversion to bioethanol (Figure 1.1) ${ }^{37}$. There are three main goals of pretreatment, improving the formation of sugars, avoiding the degradation of carbohydrates, and avoiding the formation of byproducts that will inhibit later stages of the fermentation process ${ }^{37}$. It is also desirable for the pretreatment to have low capital cost, operational cost, and energy demand, especially since pretreatment is one of the most expensive stages in the conversion of lignocellulosic biomass into bioethanol ${ }^{38}$.

There are a few main categories of pretreatment methods that can be used individually or in conjunction with one another. These categories are physical, physiochemical, chemical, biological, or electrical ${ }^{37}$. Physical methods include grinding, shredding, milling, pyrolysis, and high-energy radiation ${ }^{38}$. These can be energy intensive and operations like milling are usually combined with chemical pretreatment ${ }^{38}$. Physiochemical pretreatment methods include steam explosion, liquid hot water pretreatment, ammonia fiber expansion (AFEX), and carbon dioxide explosion ${ }^{37}$. Chemical pretreatment includes ozonolysis, acid treatment, alkali treatment, organosolv, and others ${ }^{37}$. A summary of the limitations and benefits of various pretreatments can be found in Table 1.3.

Table 1.3. Summary of various methods of pretreatment of lignocellulosic biomass. Adapted from ${ }^{37,38}$

\begin{tabular}{lll} 
Pretreatment Process & Advantages & Disadvantages \\
\hline Mechanical comminution & $\begin{array}{l}\text { Reduces cellulose } \\
\text { crystallinity }\end{array}$ & Large energy demand \\
\hline
\end{tabular}




\begin{tabular}{|c|c|c|}
\hline High-energy radiation & $\begin{array}{l}\text { Disrupts cells at ambient } \\
\text { conditions }\end{array}$ & $\begin{array}{l}\text { Needs more research and } \\
\text { requires another form of } \\
\text { pretreatment }\end{array}$ \\
\hline Steam explosion & $\begin{array}{l}\text { Limited chemicals; } \\
\text { degrades hemicellulose and } \\
\text { transforms lignin }\end{array}$ & $\begin{array}{l}\text { Destroys portion of xylans, } \\
\text { and possible disruption of } \\
\text { fermentation; Incomplete } \\
\text { destruction of lignin }\end{array}$ \\
\hline Liquid hot water & Low cost; Few inhibitors & $\begin{array}{l}\text { Energy demanding, lower } \\
\text { concentration of products } \\
\text { compared to steam } \\
\text { explosion }\end{array}$ \\
\hline AFEX & $\begin{array}{l}\text { Increase in surface area; } \\
\text { removes a large portion of } \\
\text { lignin and hemicellulose; } \\
\text { no inhibitors }\end{array}$ & $\begin{array}{l}\text { Not efficient for high } \\
\text { lignin content; cost and } \\
\text { environment concerns with } \\
\text { ammonia }\end{array}$ \\
\hline Carbon dioxide explosion & $\begin{array}{l}\text { Low cost; High solids } \\
\text { loading; no inhibitors }\end{array}$ & $\begin{array}{l}\text { High pressures require } \\
\text { expensive equipment; does } \\
\text { not modify lignin or } \\
\text { hemicelluloses }\end{array}$ \\
\hline Ozonolysis & $\begin{array}{l}\text { Reduces lignin content; no } \\
\text { inhibitors }\end{array}$ & $\begin{array}{l}\text { Expensive due to large } \\
\text { quantities of ozone }\end{array}$ \\
\hline Acid treatment & $\begin{array}{l}\text { Breaks down hemicellulose } \\
\text { and alters lignin structure }\end{array}$ & $\begin{array}{l}\text { High cost; equipment must } \\
\text { resist corrosion }\end{array}$ \\
\hline Alkaline treatment & $\begin{array}{l}\text { Increases surface area; } \\
\text { removes hemicellulose and } \\
\text { lignin }\end{array}$ & $\begin{array}{l}\text { Long residence time; salts } \\
\text { are difficult to recover } \\
\text { from biomass }\end{array}$ \\
\hline Organosolv & $\begin{array}{l}\text { Breaks down hemicellulose } \\
\text { and lignin }\end{array}$ & $\begin{array}{l}\text { Solvents need to be } \\
\text { removed and collected; } \\
\text { high cost }\end{array}$ \\
\hline
\end{tabular}

\subsubsection{GVL Pretreatment Method}

GVL pretreatment is an organosolv method and utilizes a dilute acid catalyst, which has several benefits over an aqueous acid pretreatment ${ }^{39}$. While it is a newer pretreatment method, it has been tested on several different biomass types including corn stover, hardwoods, and softwoods and has proved to be an effective method of fractionation ${ }^{11}$. 
The pretreatment process, which uses a solution of GVL, water, and sulfuric acid, can completely depolymerize biomass so that all components are solubilized into the GVL solution ${ }^{6}$. This is important because GVL prevents the lignin from precipitating onto the cellulose fraction, which allows for greater accessibility of the cellulose fraction for further depolymerization than when only water is used as the solvent ${ }^{6}$. Since this process can fractionate the lignocellulose, it allows for easier recovery and conversion of the lignin, hemicellulose, and cellulose portions into separate value-added products ${ }^{39}$. Furthermore, because GVL can be produced from biomass, a biorefinery using this method has the potential to be self-sustaining ${ }^{6}$.

GVL pretreatment typically consists of a solution with 70-90\% GVL in water with a small amount of sulfuric acid at $120{ }^{\circ} \mathrm{C}$ to extract lignin and continues to reach higher temperatures between $180-226^{\circ} \mathrm{C}$ to break down the cellulose (Figure 1.5) ${ }^{6,11,39}$. The temperature increases over the duration of the pretreatment to extract first the lignin and hemicellulose fractions, and then the cellulose at the higher temperatures ${ }^{6}$. After pretreatment, either salts or carbon dioxide can be used to separate the sugar containing aqueous phase and the GVL phase, which can be recycled ${ }^{11}$.

Other variations have been investigated, including a more dilute concentration of GVL with use in a more cellulose-rich biomass compared to lignocellulosic biomass ${ }^{39}$. Other studies have considered the use of hydrochloric acid instead of sulfuric acid and have found it to be more effective at lower temperatures ${ }^{40}$. The GVL solution can also be paired with an organic cosolvent, such as benzene or toluene, that does not negatively affect the sugar formation, but does form two separate phases, an organic and aqueous phase, at room temperature. The aqueous phase contains the sugars to be used for further processing ${ }^{6}$. This method also avoids the complications in downstream processing caused by the salts acting as an inhibitor on microbial growth ${ }^{6}$. 


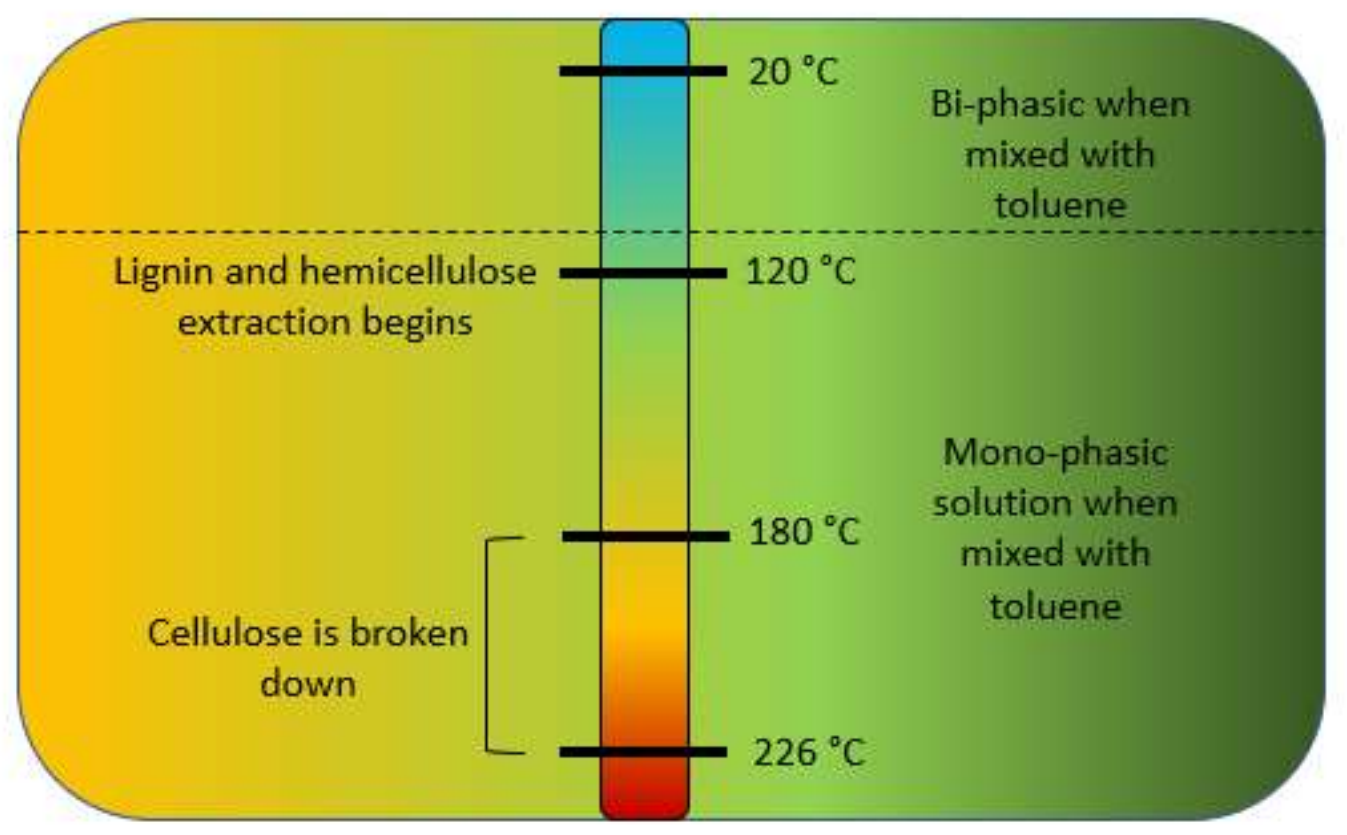

Figure $1.5 \mathrm{GVL}$ pretreatment is carried out between $120^{\circ} \mathrm{C}$ and $226^{\circ} \mathrm{C}$. When mixed with toluene for separation, the solution is bi-phasic at low temperatures and monophasic at high temperatures. Based on ${ }^{6}$.

\subsection{Previous Biorefinery Studies}

The extraction of waxes from biological sources is not a new concept and has been considered for integration into a biorefinery in other studies. Several of these studies consider the use of supercritical carbon dioxide extractions on miscanthus, straw, and maize stover biomasses ${ }^{41-44}$. The supercritical extraction step was proposed to take place prior to a combination of mechanical processing and other pretreatment methods, similar to the solvent extractions in Nigheim et al $^{23}$. The supercritical carbon dioxide extractions were found to increase sugar production from the pretreatment. Supercritical carbon dioxide has a low impact on the environment, but does require significant energy and expensive equipment ${ }^{41}$.

A more recent study conducted by Scopel et al. considered the use of green solvents to perform extractions prior to pretreatment methods ${ }^{45}$. However, the solvents considered were polar and used to obtain fatty acids, sterols, alcohols and phenolics from elephant grass. After extraction, the biomass underwent enzymatic hydrolysis. It was found that the extraction did not hinder the enzymes and that there was actually an increase in the release of sugar during hydrolysis ${ }^{45}$.

While these studies have avoided the use of hexane, a toxic and nonrenewable solvent, they have not considered green organic solvents as replacements followed by a GVL pretreatment in an integrated biorefinery. This approach would help to mitigate not only 
the use of hexane, but also does not require the biomass to be processed or altered between the extraction and pretreatment. This is unlike the supercritical carbon dioxide model, which requires a physical pretreatment prior to subsequent thermochemical or biological processing ${ }^{41}$. Furthermore, the use of more non-polar organic solvents should target the extraction of the valuable waxes and lipids, unlike with the use of ethanol and other more polar solvents ${ }^{45}$. 


\section{Methods and Materials}

\subsection{Sorghum Biomass and Solvents}

The biomass used in these experiments was 2014 Sorghum grown at the DOE-Great Lakes Bioenergy Research Center's (GLBRC) Biofuel Cropping Systems Experiments (BCSE) located at the Arlington Agricultural Research Station in southcentral Wisconsin, USA (ARL 4317 ' 45" N, 8922' 48” W, $315 \mathrm{~m}$ a.s.l. The annual temperature is $6.9^{\circ} \mathrm{C}$ and the precipitation is $869 \mathrm{~mm}^{46}$. The soil type at this location is Plano silt loam. This soil is fine-silty, mixed, super active, mesic Typic Argiudoll; well-drained. Mollisol developed over glacial till and formed under tallgrass prairie. Sorghum was sourced from ARLAUX TRIAL in 2014. The harvested plant materials were dried in a $60{ }^{\circ} \mathrm{C}$ oven, milled to $5 \mathrm{~mm}$ using a Christy Turner mill (Christy Turner Ltd. Suffolk, UK) and stored in sealed bags until use.

The solvents used were n-hexanes ( $\geq 99 \%)$, 2-methyltetrahydrofuran $(\geq 99 \%), \gamma$ valerolactone ( $\geq 99 \%$ ), and diethoxymethane (99.7\%), all purchased from MilliporeSigma.

\subsection{Reactor System}

The reactor system was used for both the extractions and the pretreatment experiments (Figure 2.1). It consisted of a custom pretreatment system consisting of three parallel, $42.1 \mathrm{~mL}$ tubular (20.32 cm length, $1.63 \mathrm{~cm}$ ID) reactors constructed from Hastelloy (Figure 2.2). Solvents were added to the system using a Cole-Parmer Masterflex highflow dual piston pump, without dampener (PN: PR100SFX14CP). The liquids leaving the reactor pass through a bath that can be filled with ice water to cool acidic liquids and prevent corrosion of the stainless-steel collection vessels. Pressure in the system was controlled by applying nitrogen gas and adjusting a back pressure regulator attached to each reactor. 


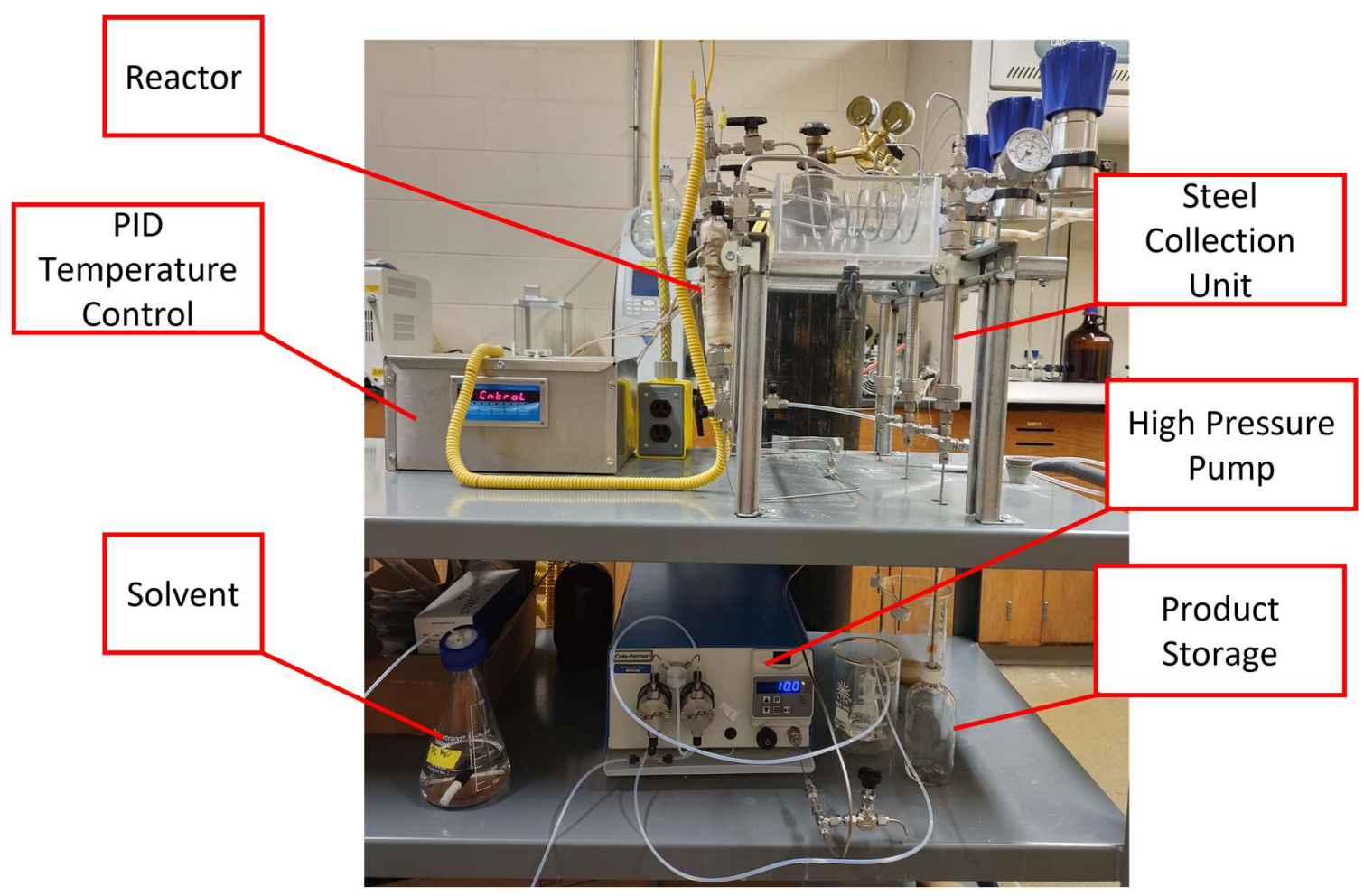

Figure 2.1 Photograph of reactor system with key components labeled. 


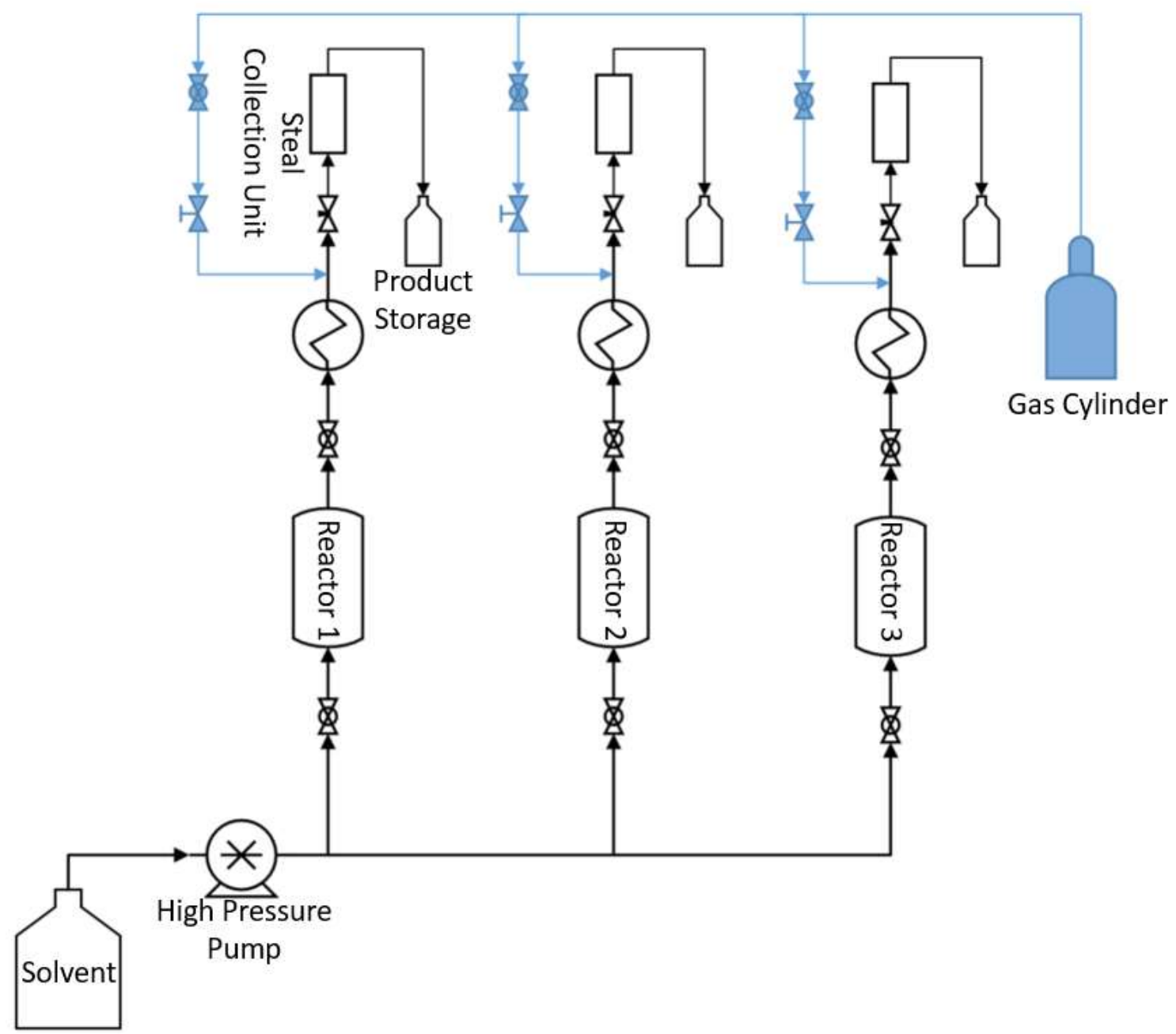

Figure 2.2. Reactor system used for extractions. Solvent flows from the reservoir through the desired reactors and into the appropriate collection and storage vessel. Backpressure applied using the gas lines in blue.

\subsection{Lipid Extraction}

Extractions were performed with three different solvents (hexane, 2methyltetrahydrofuran, or diethoxymethane) at four different temperatures $\left(25^{\circ} \mathrm{C}, 40^{\circ} \mathrm{C}\right.$, $60^{\circ} \mathrm{C}$, or $80^{\circ} \mathrm{C}$ ), in triplicate. Prior to performing an extraction, $\sim 500 \mathrm{~mL}$ of solvent was transferred to a glass media bottle and degassed in an ultrasonic bath for $1 \mathrm{hr}$ to avoid any volatilization of solvent in the high-pressure pump. Five grams of biomass were loaded into each reactor between two pieces of glass wool ( $\sim 0.5 \mathrm{~g}$ each). After the cells were prepared, the pump was primed and set to run at $10 \mathrm{~mL} / \mathrm{min}$. Three extractions were run in each vessel using the same solvent. The solvent was allowed to fill the cell for 5 minutes or until solvent was seen dripping into the collection bottle. This was to verify that the cell was filled and there was no blockage in the piping. The valves from the pump and to the collection vessel were closed and the reactor pressurized to 300 psi using 
nitrogen. After the 5-minute ramp to the desired temperature, the extractor was held at temperature for 30-minutes. It should be noted that the DEM trials were conducted at 350 psi. At the end of this time, the reactor was slowly depressurized to prevent flashing and fresh solvent was pumped through the system for 6 minutes at $10 \mathrm{~mL} /$ minute to ensure that all the extractable material was collected. The total volume of extract was recorded, and it was stored in a glass bottle in a flammable freezer $\left(-20^{\circ} \mathrm{C}\right)$ until further use. The biomass was unloaded and placed in a dryer box for several days until the solvent was evaporated. It was then weighed, and the moisture content was analyzed by weighing samples before and after being placed in a $105^{\circ} \mathrm{C}$ oven overnight. The entire pretreatment system was flushed with fresh solvent prior to beginning extractions with that solvent.

\subsection{Solvent Evaporation and Lipid Collection and Analysis}

Following extraction, the solvents, hexane, MeTHF, and DEM, were evaporated from collected extracts so that the solid lipids could be collected and analyzed. The solvents were evaporated using a rotary evaporator (SpeedVac Savant SC201A). The flasks were weighed before and after evaporation to determine the mass of solid that remained in the flask. The SpeedVac was set to $40{ }^{\circ} \mathrm{C}$ for approximately 1.5 hours, and then extended if sample was not yet dry. The dry lipids were then scraped and stored in microcentrifuge tubes for shipping and further analysis.

The dry lipids were sent to Texas A\&M and evaluated using GC-MS. Waxes were transferred to autosampler vials for analysis by resuspension in hexane, then dried under a nitrogen stream so that the hexane is evaporated. The transferred mass was then verified on a Mettler Toledo MS104S with a resolution $0.1 \mathrm{mg}$ before adding $300 \mu \mathrm{L}$ of N,O-bis(trimethylsilyl)trifluoroacetamide (BSTFA) with $1 \%$ trimethylchlorosilane (TMCS) under a nitrogen stream before being incubated at $85^{\circ} \mathrm{C}$ for 12 hours. After incubation excess BSTFA was evaporated under nitrogen. Following this, $1 \mathrm{~mL}$ of chloroform with $10 \mu \mathrm{g} / \mathrm{mL}$ tetracosane was added to each sample as an internal standard. Samples were then analyzed on an Agilent 7890A/7693A/5975C XL GC-MS equipped with a $0.25-\mathrm{mm}$ DB-5MS column $(0.25-\mathrm{mm}$ film) using pulsed splitless injection. Helium was used as the carrier gas at $105.75 \mathrm{~mL} / \mathrm{min}$. The oven was held at $70^{\circ} \mathrm{C}$ for $1 \mathrm{~min}$, then ramped by $10^{\circ} \mathrm{C} / \mathrm{min}$ to $200{ }^{\circ} \mathrm{C}$, then subsequently ramped by $4{ }^{\circ} \mathrm{C} / \min$ to $295^{\circ} \mathrm{C}$ that was held for $20 \mathrm{~min}$ (total run time 57.75 minutes). The MS Source was held at 230 ${ }^{\circ} \mathrm{C}$ and the MS Quad at $150{ }^{\circ} \mathrm{C}$. Scan range was 200 to $550 \mathrm{~m} / \mathrm{z}$. Injection volumes were $1-4 \mu \mathrm{L}$, depending on signal to noise ratio.

\subsection{GVL Pretreatment}

GVL pretreatment was only conducted on the most effective temperature extraction for each solvent: $60^{\circ} \mathrm{C}$ for hexane, and $80^{\circ} \mathrm{C}$ for both DEM and MeTHF. For each trial, the extractions were performed as described previously and the biomass was left inside the cell following the extraction. The solvent was drained from the reactor system and ice was added to the ice bath reservoir after the reaction cells to act as a heat exchanger. 
Then, a $500 \mathrm{~mL}$ solution of $80 \%$ GVL: $20 \%$ water with $60 \mathrm{mmol}$ sulfuric acid was pumped into the cells until full, as previously described in the extraction procedure. To begin Stage 1 the cells were pressurized to $300 \mathrm{psi}$, heated to $165^{\circ} \mathrm{C}$ and then held at temperature for 90 minutes. Once Stage 1 ended, pure GVL was pumped through the pressurized cell as the temperature was ramped at a rate of $3.8^{\circ} \mathrm{C} / \mathrm{min}$ during Stage 2 . The collection valve was opened as necessary to collect the products of Stage 1 (Figure 2.3).

Once the internal temperature reached $220^{\circ} \mathrm{C}, 500 \mathrm{~mL}$ of an $80 \% \mathrm{GVL}: 20 \%$ water solution containing $1 \mathrm{mmol}$ of sulfuric acid was substituted for the pure GVL and Stage 3 began. At this time, the collection of Stage 1 was completed and the temperature allowed to continue ramping until reaching the final temperature set point of $280{ }^{\circ} \mathrm{C}$. The increase from $165^{\circ} \mathrm{C}$ to $280^{\circ} \mathrm{C}$ took 30 minutes. Once the final temperature was reached, Stage 2 collection was completed. The remaining extracted liquid was periodically collected until the product became very pale in color. The system was then drained and allowed to cool before removing the cells.

There was a small amount of biomass remaining in the reactor cell following pretreatment, that was not broken down, likely due to it being slightly out of range of the heated region of the reactor and did not reach the appropriate temperatures. Although this mass was not able to be recorded for two of the samples, it is assumed that the amount was similar for all samples of the same solvent.

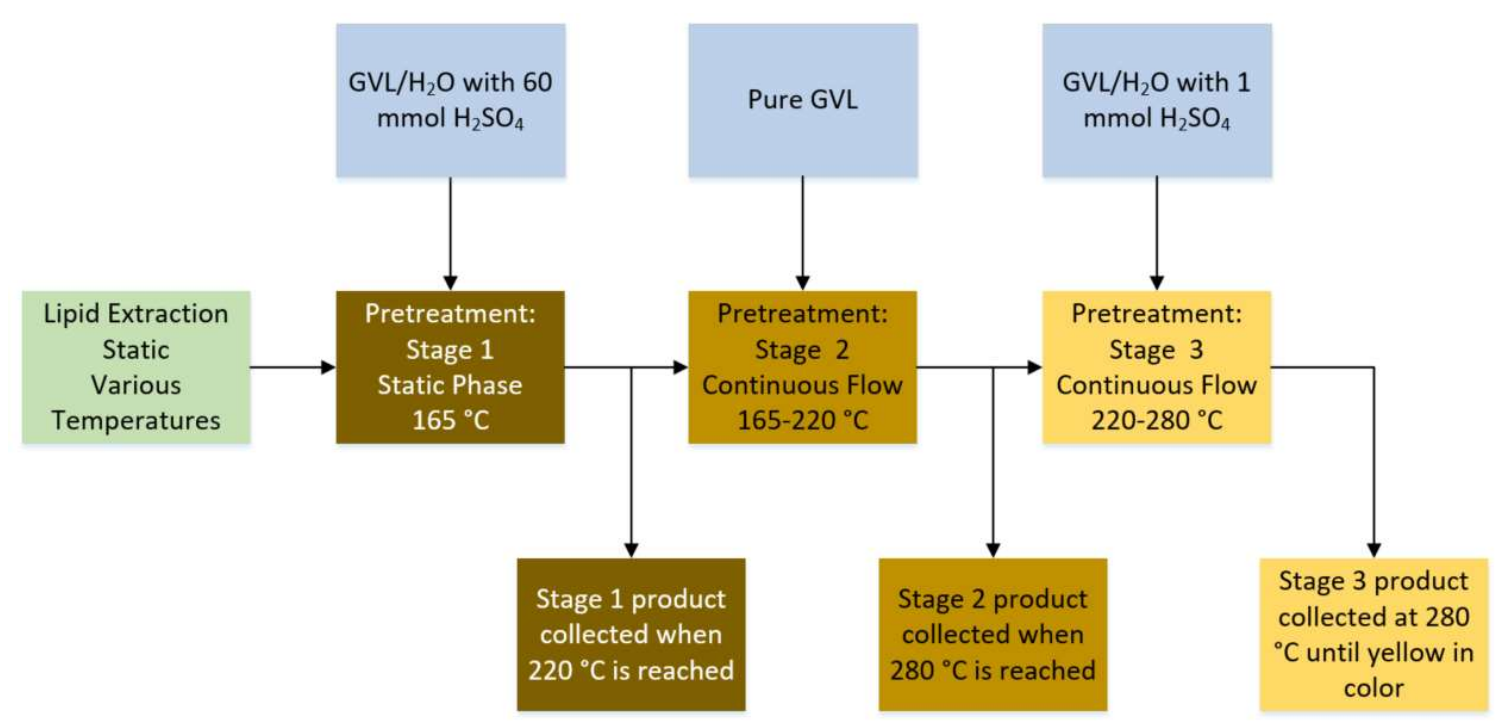

Figure 2.3 GVL pretreatment following extraction consists of three stages with three separate solvents used and three products collected. 


\subsection{Lignin and Sugars Separation}

To separate the lignin, distilled water was mixed with the lignin and hemicellulose hydrolysate in a ratio of 9:1 (vol:vol) and allowed to settle for two days. A sample of the liquid phase was taken for product analysis. The rest of the liquid was decanted and filtered through an $11 \mu \mathrm{m}$ filter so that only a small amount remained on top of the precipitated lignin. The precipitate with residual liquid was centrifuged and decanted until all the lignin was collected. The lignin precipitate was washed with $75^{\circ} \mathrm{C}$ water. The lignin precipitate and the lignin collected via filtration were allowed to dry in an oven at $50{ }^{\circ} \mathrm{C}$ overnight, weighed, and the mass recorded. A portion of each liquid product was washed with 1:1 (vol:vol) toluene four times and then filtered through a 0.2 $\mu \mathrm{m}$ filter before being sent for quantification of sugars and other components. After product analysis, the mass balance was completed. The overall sugar yield was completed on a mass basis. The amount of formate produced from xylose and glucose respectively was calculated using a mole balance where 1 mole of glucose produced 1 mole of formate. It was assumed the remaining formate was a product of the xylose. The mass of the formate was distrubeted accordingly and included in the overall mass balance and yield calculations. 


\section{Results and Discussion}

\subsection{Lipid Extraction}

The mass of lipids extracted tends to increase as the temperature of the extraction increases. It was found that on average DEM and MeTHF performed best at $80^{\circ} \mathrm{C}$. However, hexane removed the most mass at $60^{\circ} \mathrm{C}$ (Figure 3.1). The MeTHF extracted more lipids at $80^{\circ} \mathrm{C}$ than either of the solvents did at any temperature (Figure 3.2). DEM extracted slightly more than hexane at all temperatures. The MeTHF extraction at $80{ }^{\circ} \mathrm{C}$ was able to extract an average of $2 \mathrm{wt} \%$ of the biomass, compared to hexane at $60{ }^{\circ} \mathrm{C}$ and DEM at $80{ }^{\circ} \mathrm{C}$, which extracted $0.7 \mathrm{wt} \%$ and $1.1 \mathrm{wt} \%$ respectively. Sorghum is $0.2 \mathrm{wt} \%$ wax and $3.6 \mathrm{wt} \%$ oil, indicating that none of the solvents extracted the full amount of waxes and oils from the sorghum ${ }^{18}$.

Based on this information, the extractions prior to pretreatment were performed at the ideal temperature for each respective solvent. These temperatures were chosen since they had the highest average lipid extraction and were similar to industrial extraction conditions. Hexane extractions in industry are performed at $55^{\circ} \mathrm{C}$, which agrees with the data that indicated the best temperature to be near $60^{\circ} \mathrm{C}{ }^{47}$. The lipid yield from MeTHF at $80^{\circ} \mathrm{C}$ was significantly higher than at $25^{\circ} \mathrm{C}$ and so the higher temperature was used. While the average data was more scattered for DEM, the highest amount was extracted at $80^{\circ} \mathrm{C}$. The amount collected at the optimum was noticeably higher than at ambient, with the values being $28.4 \%, 68.0 \%$, and $25.1 \%$ greater for hexane at $60{ }^{\circ} \mathrm{C}$, MeTHF at $80^{\circ} \mathrm{C}$, and DEM at $80^{\circ} \mathrm{C}$, respectively.

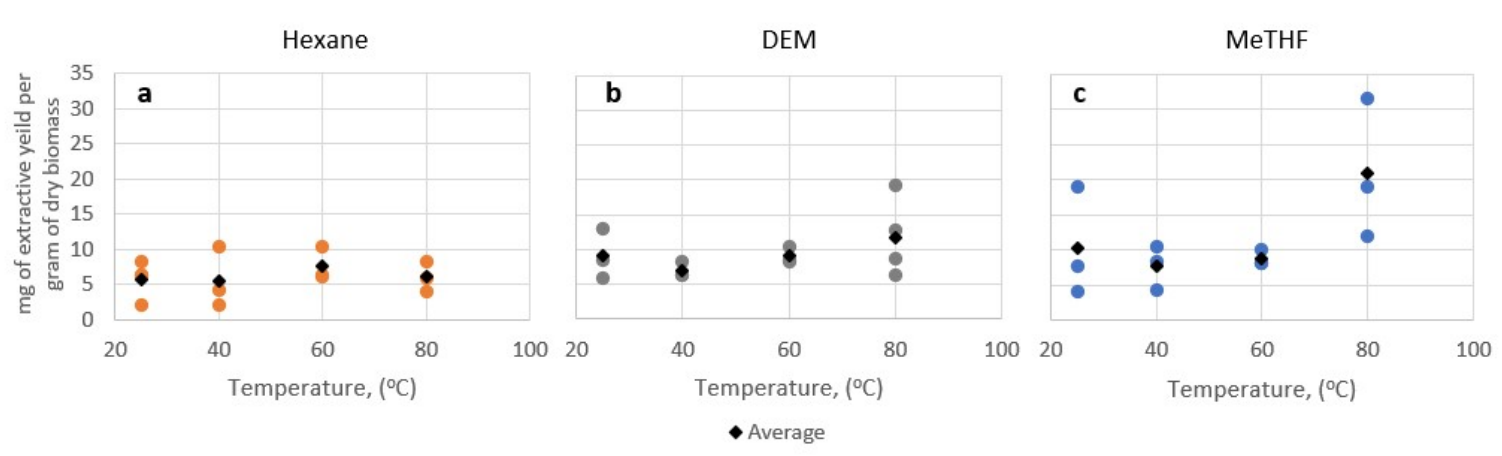

Figure 3.1 Quantity of sorghum extractives recovered using a) hexane, b) DEM, and c) MeTHF with average values indicated for comparison. 


\subsection{Lipid Contents}

The lipids extracted using hexane were found to contain noticeable amounts of fatty acids and alcohols including: palmitic acid, steric acid, octacosanol, and octacosanoic acid. The majority of the peaks were identifiable using standards (Figure 3.2). Fatty alcohols and some fatty acids, though the presence of fatty acids has been debated, are found in sorghum waxes ${ }^{18}$. Sorghum wax also contains significant proportions of wax esters ${ }^{18}$. However, wax esters were not able to be detected using our method, and it is possible that sample preparation hydrolyzed them into their fatty acid and alcohol components. Many of the compounds detected in sorghum waxes by previous studies were also seen in the hexane extractions ${ }^{18}$. However, very few of these were seen in the MeTHF and DEM extractions (Table 3.1). 

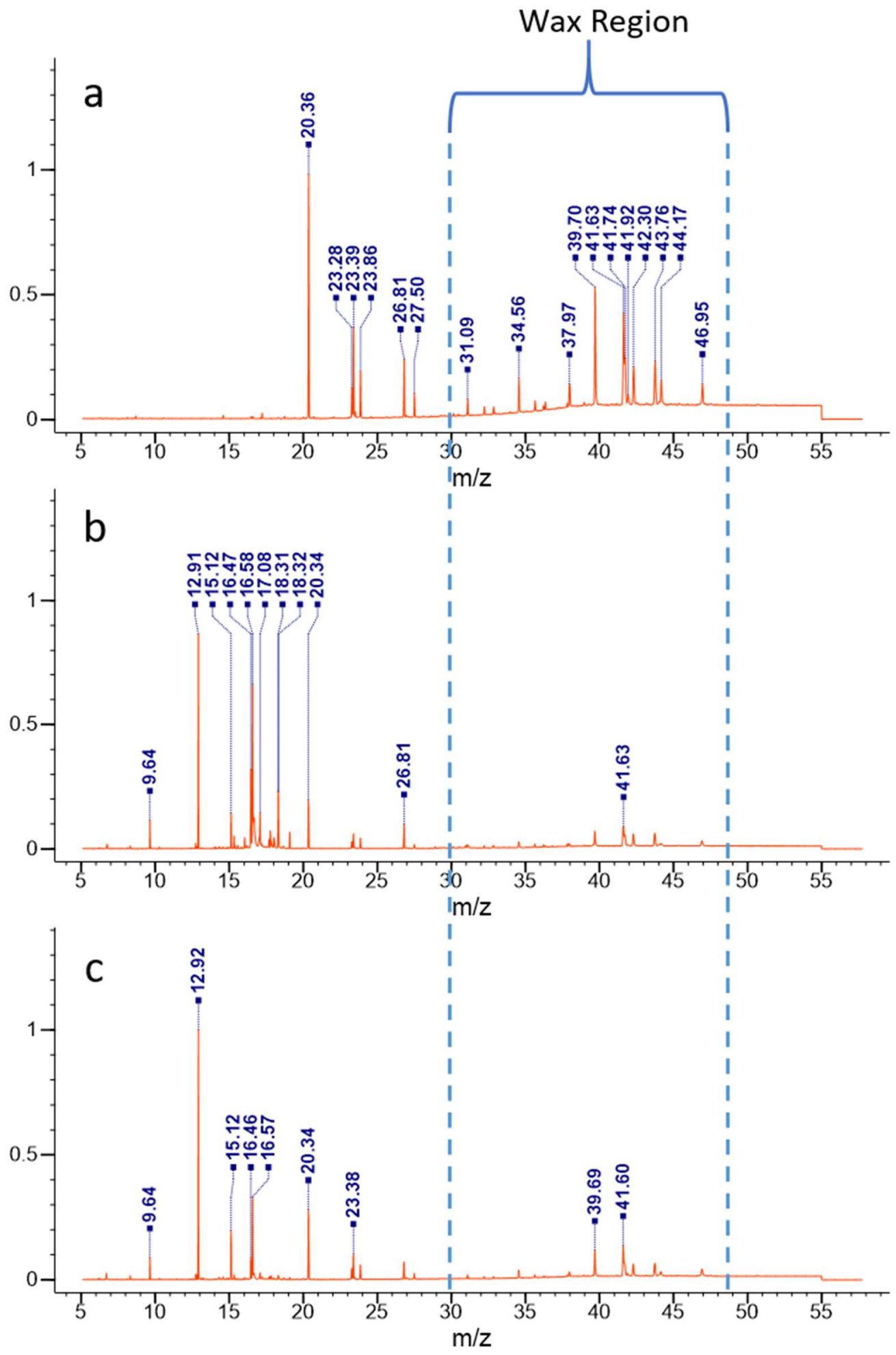

Figure 3.2 Representative chromatograms of lipids collected across all temperatures from a) hexane, b) MeTHF, c) DEM extractions with wax region indication across all graphs. 
Table 3.1 Compounds detected in chromatograms for hexane, MeTHF, and DEM with length of carbon chains and desired wax compounds bolded.

\begin{tabular}{lcccc}
\hline Compound & $\begin{array}{c}\text { Number of } \\
\text { Carbons in } \\
\text { Chain }\end{array}$ & $\begin{array}{c}\text { Retention } \\
\text { Time for } \\
\text { Hexane }\end{array}$ & $\begin{array}{c}\text { Retention } \\
\text { Time for } \\
\text { MeTHF }\end{array}$ & $\begin{array}{c}\text { Retention } \\
\text { Time for } \\
\text { DEM }\end{array}$ \\
\hline Palmitic Acid & 16 & & 20.34 & \\
\hline Possible Fatty Acid & 18 & - & 23.38 & 23.38 \\
\hline Steric Acid & 18 & & 23.86 or 23.87 & \\
\hline Tetracosane & 24 & & 26.81 & \\
\hline Possible Fatty Acid & 20 & 27.5 & - & - \\
\hline Possible Fatty Acid & $\mathbf{2 2}$ & $\mathbf{3 1 . 0 9}$ & - & - \\
\hline Heptacosane & $\mathbf{2 7}$ & $\mathbf{3 2 . 2}$ & - & - \\
\hline Possible Fatty Acid & $\mathbf{2 4}$ & $\mathbf{3 4 . 5 6}$ & - & - \\
\hline Nonacosane & $\mathbf{2 9}$ & $\mathbf{3 5 . 6 5}$ & - & - \\
\hline Possible Fatty Alcohol & $\mathbf{2 6}$ & $\mathbf{3 6 . 3 3}$ & - & - \\
\hline Hexacosanoic Acid & $\mathbf{2 6}$ & $\mathbf{3 7 . 9 7}$ & - & \\
\hline Octacosanol & $\mathbf{2 8}$ & & $\mathbf{3 9 . 6 9}$ or 39.70 & \\
\hline Octcosanoic Acid & $\mathbf{2 8}$ & & $\mathbf{4 1 . 6 3 - 4 1 . 9 2}$ & \\
\hline Possible Triterpene/Steroid & 30 & & $42.30-43.76$ & \\
\hline Melyssil Alcohol & $\mathbf{3 0}$ & $\mathbf{4 4 . 1 7}$ & - & $\mathbf{4 4 . 1 7}$ \\
\hline Melissic Acid & $\mathbf{3 0}$ & & $\mathbf{4 6 . 9 5}$ or 47.07 & \\
\hline
\end{tabular}



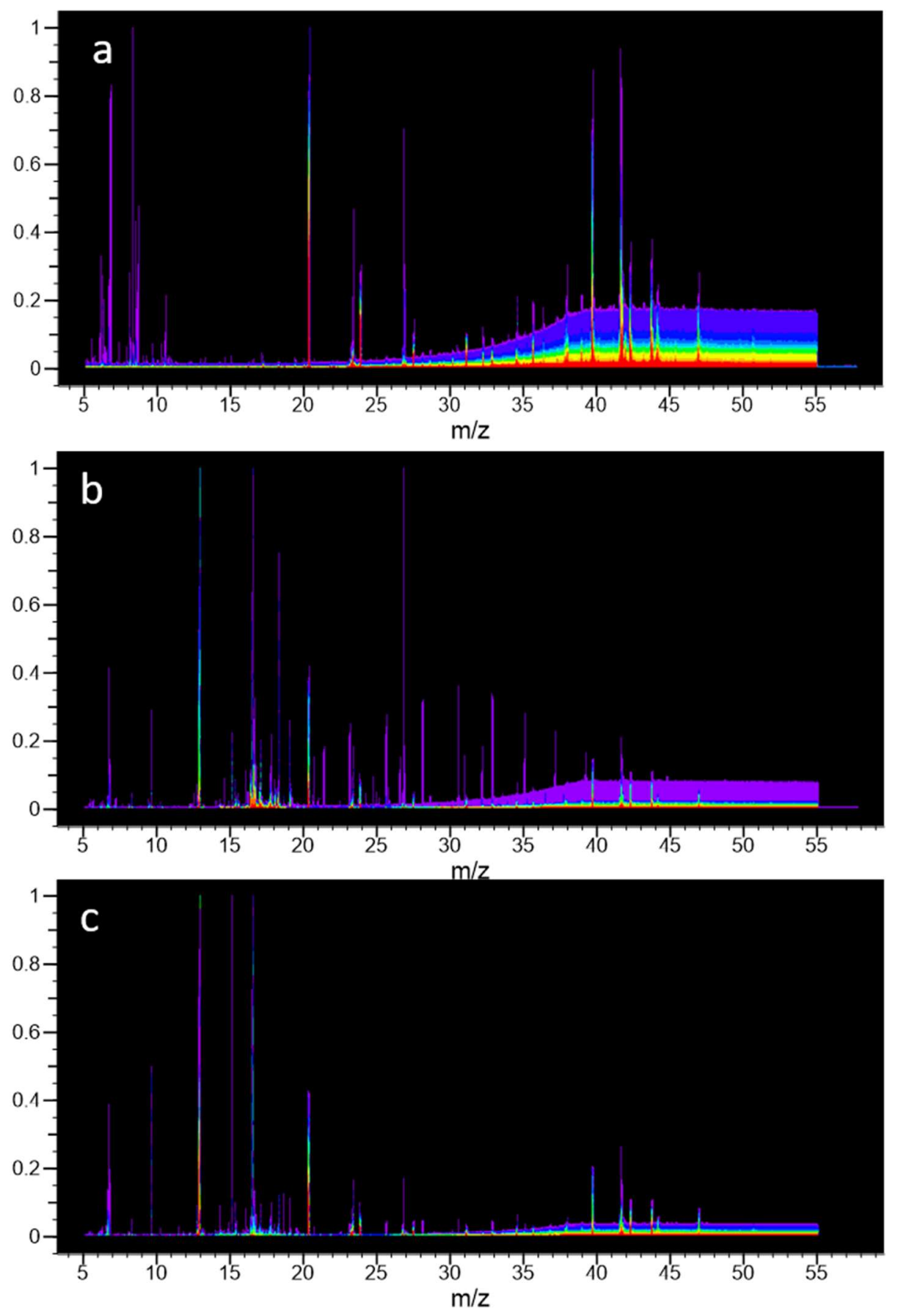

Figure 3.3 Chromatogram heat map of lipids collected across all temperatures from a) hexane, b) MeTHF, c) DEM extractions where red indicates most overlap between the different chromatograms and violet the most unique peak regions.

The lipids collected from MeTHF extractions had the least baseline overlap compared to hexane and DEM (Figure 3.3). This may indicate a lower quality of waxes, however 
there were a large number of unidentifiable components in the times ranging between 12.92 and 16.57 minutes. While MeTHF still extracted some of the same compounds as hexane, several were not detected. This was similar to results found by S.S. de Jesus et al., who found that MeTHF did have a higher total lipid extraction from microalgae, but also had a higher selectivity toward certain fatty acids in the C14-C20 range, which is lower than would be desirable for wax extraction ${ }^{33}$. This trend can be seen by the higher peaks in the 20-26 minute range in Figure 3.2. Similarly, Sicaire et al. reported that MeTHF extracted more carotenoids and volatile aroma compounds from carrots and black currants, but when the composition was considered, it had extracted smaller amounts of desired oxygenated and non-oxygenated compounds than hexane ${ }^{32}$. This is likely because MeTHF has oxygen atoms and can extract more polar compounds that are not easily identified or desired ${ }^{47}$.

The lipids extracted using DEM had several unknowns at similar times as the MeTHF lipids between 12.92 and 16.57. Similarly to MeTHF, it extracted more of the smaller carbon chain molecules. This was also demonstrated in Zeng et al., who found that DEM was more effective than hexane at extracting fatty acids containing between 16 and 18 carbons ${ }^{31}$. DEM also contains oxygen atoms, making it more likely than hexane to extract polar molecules. However, there was more overlap with the baseline than indicated in the MeTHF plots (Figure 3.3). This overlap may indicate that the waxes extracted by DEM are a higher quality than those extracted by MeTHF since the baseline contains more known and desired waxes. However, neither MeTHF nor DEM extracted a comparable amount of quality waxes to hexane.

\subsection{Lignin and Sugars}

\subsubsection{Sugars}

The sugar concentrations were analyzed to determine if the lipid extraction would impact the conversion to bioethanol. It was found the amount of glucose extraction was very similar with the hexane samples producing $20.90 \mathrm{mg} / \mathrm{g}$ of dry biomass on average, the MeTHF producing $17.80 \mathrm{mg} / \mathrm{g}$ dry biomass, and DEM $20.05 \mathrm{mg} / \mathrm{g}$ dry biomass (Figure 3.4). There was $16.0 \%$ difference between the amounts produced by the highest yield samples and the lowest yield. While hexane produced slightly more glucose, it did not produce the most xylose. DEM samples produced $27.23 \mathrm{mg} / \mathrm{g}$ dry biomass used, hexane $18.36 \mathrm{mg} / \mathrm{g}$ dry biomass, and MeTHF $17.23 \mathrm{mg} / \mathrm{g}$ dry biomass. This was a more significant difference and indicated that the DEM extraction impacted the hydrolysis of the hemicellulose, but not the glucose. This is further indicated by the larger amount of xylose-derived formate found in the DEM samples compared to the other two solvents. However, the monomeric sugar yield was much lower than found in other studies and the LA yield much higher, regardless of solvent used ${ }^{11}$. This is likely due to the higher temperatures at which this experiment was conducted. 


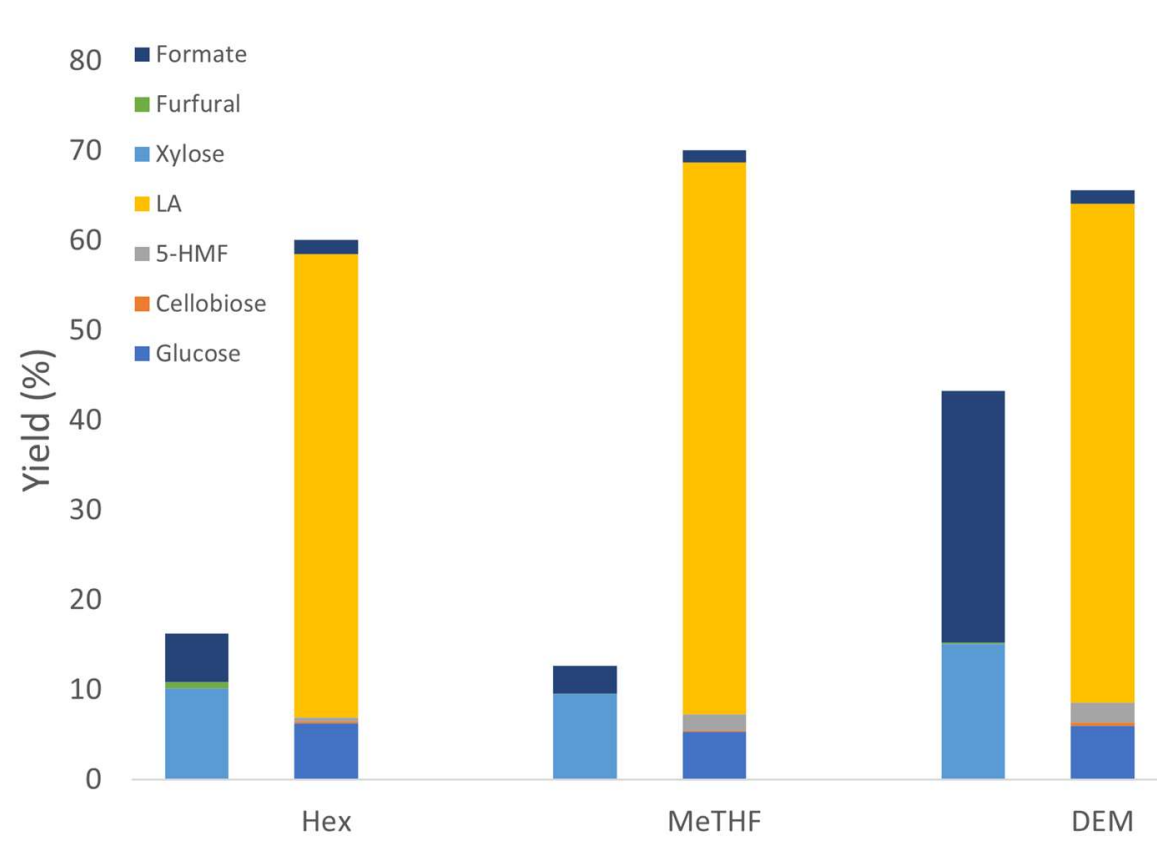

Figure 3.4 GVL pretreatment sugar products yield of total starting sorghum sugar content $^{48}$ for each extraction solvent used

An additional finding related to products was the large amount of ethanol in the pretreatment yields for the DEM samples. The pretreatment products from the hexane samples contained an average of $4.7 \pm 2.1 \mathrm{mg}$ ethanol per gram of dry biomass, the MeTHF samples $2.1 \pm 0.4 \mathrm{mg} /$ gram dry biomass, and the DEM samples $524.6 \pm 164.0$ $\mathrm{mg}$ /gram dry biomass. The large amounts of ethanol could be due to acid-catalyzed cleavage of the DEM. The ratio of concentration of ethanol to sugars, including xylose, glucose, and cellobiose, in the sample is $0.0042,0.0021$, and 0.3756 for hexane, MeTHF, and DEM samples respectively. This larger ratio in the DEM samples may be cause for concern as excess ethanol can inhibit fermentation of the sugars.

\subsubsection{Sugar Degradation Compounds}

The samples were found to contain 5-hydroxymethylfurfural (5-HMF) as well as furfural, two lignotoxins that may inhibit later conversion to bioethanol. These were both found in the Phase 1 products. Furfural was also found in the Phase 2 products, but neither was found in the Phase 3 pretreatment products. Since furfural is derived from xylose, which should be collected in the earlier phases, this is expected. While hexane produced the most furfural, the amount was much smaller compared to the amount of 5-HMF produced by any of the samples. DEM and MeTHF produced more 5-HMF than hexane (Figure 3.4). 
The aqueous pretreatment product samples were also tested for remaining GVL and toluene content that may be left after dilution and washing via liquid-liquid extraction. The diluted hexane samples contained the most GVL, with an average of $14.2 \pm 5.6 \mathrm{~g} / \mathrm{L}$ of the overall sample, followed by MeTHF with $12.6 \pm 5.2 \mathrm{~g} / \mathrm{L}$ of sample, and DEM with $12.9 \pm 5.8 \mathrm{~g} / \mathrm{L}$ of sample. On average, the hexane samples contained $49.5 \pm 12.7$ $\mathrm{mg} / \mathrm{L}$ toluene, the MeTHF samples $50.1 \pm 21.2 \mathrm{mg} / \mathrm{L}$, and the DEM $2205 \pm 4558 \mathrm{mg} / \mathrm{L}$. The DEM results were scattered and included some incomplete data and are not considered accurate. One sample had a large amount of residual toluene, while another was partially unable to be processed, leading to a large variation in the amount of toluene.

Because the MeTHF and hexane samples contained nearly identical results and the DEM data was inconclusive, it is likely that the lipid extraction solvent does not have a large effect on the amounts of toluene or GVL present after washing.

\subsubsection{Lignin Quantity}

There was also a difference in the amounts of lignin collected for each stage. The hexane and DEM samples both produced more lignin during Stage 1, but the MeTHF samples produced more lignin later, during Stage 2. This indicates that the MeTHF may have an impact on how the pretreatment is able to breakdown the lignocellulose. It is also notable that both

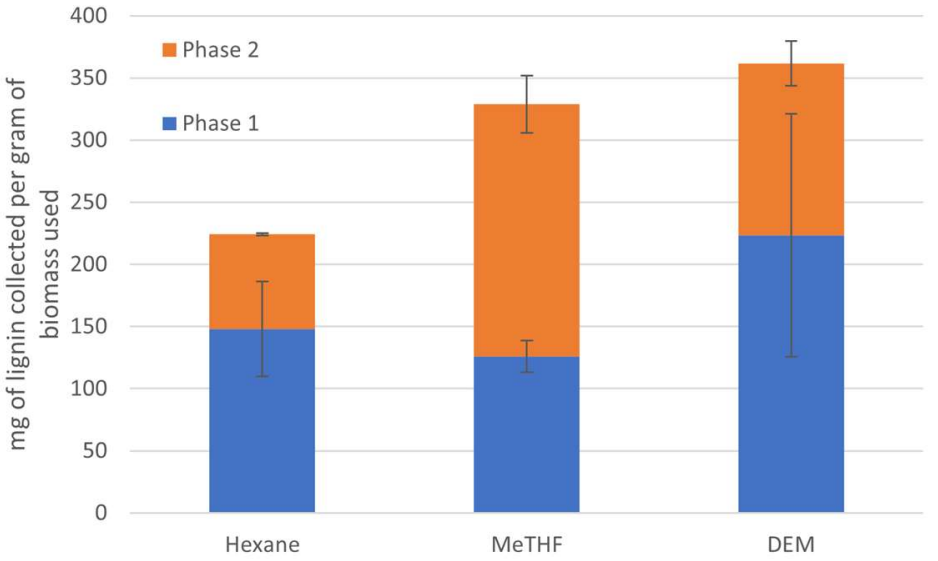

Figure 3.5 Quantity of lignin collected from Stage 1 and Stage 2 of GVL pretreatment preceded by each solvent extraction. The error bars represent the standard deviation from three replicates. the MeTHF and DEM samples had a larger precipitate yield overall than the hexane by 50 and $100 \mathrm{mg}$ lignin/gram of biomass, respectively (Figure 3.5). The lignin collected from the various solvents also behaved and appeared differently based on the solvent that had been used for the lipid extraction (Table 3.2). The dried lignin also exhibited some slight differences in coloring, though not as noticeable as during the separation process (Figure 3.6). However, the precipitate may not include only lignin, but also any remaining lipids and humins, which are difficult to distinguish from lignin without further analysis ${ }^{49}$. The large amount of xylose-derived formate in the DEM samples 
indicates that a portion of the xylose was degraded, and likely produced a substantial amount of humins, which would be present in the precipitate.

Table 3.2 Observed physical characteristics of the lignin obtained from pretreatment after lipid extractions. Observations were made during the separation process.

\section{Extraction Solvent}

Hexane

MeTHF

DEM

\section{Visible Characteristics of lignin}

Dark brown with small chunks; easily separated with very little dissolved in solvent after settling

Dark brown with larger chunks; somewhat easily separated; more prone to redissolving after settling than hexane
Lighter brown, very fine precipitate; very difficult to maintain a non-dissolved form a

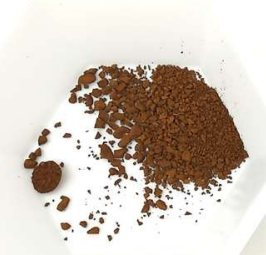

b

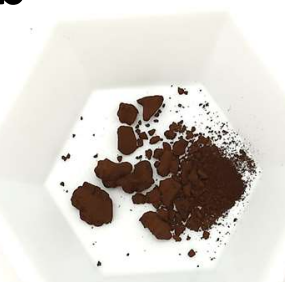

C

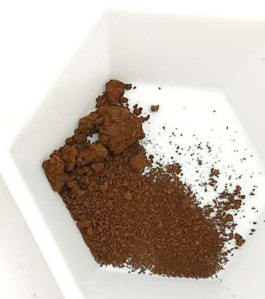

Figure 3.6 The dried lignin from a) hexane, b) MeTHF, c) DEM extracted biomass is slightly different colored, even when dry. The colors are not as obvious as those observed during separation.

\subsubsection{System Mass Balance}

A mass balance was performed on the primary products including the lipids, sugars, sugar degradation products, lignin, and levulinic acid (Figure 3.7). In the example shown, $80.7 \%$ of the input is accounted for. This is somewhat representative of the whole 
set of samples, which on average, were able to account for $89.9 \%$ of the starting material. Any deviation may be explained by losses in biomass to ash, unaccounted for oligomers sugars or organic acids, as well as other side products. Oligomers have previously been found in GVL pretreatment products. ${ }^{11}$ This is likely the cause of the low overall values in the hexane and DEM mass balances. Lignin precipitate and levulinic acid were produced in the largest quantities from all processes (Table 3.3Error! Reference source not found.). The precipitate was likely a combination of the lignin and a large amount of the degraded xylose that could not be accounted for in yield calculations. Levulinic acid, produced here in high amounts, can be used for the production of GVL, MeTHF and other solvents which can sold or converted to fuels .

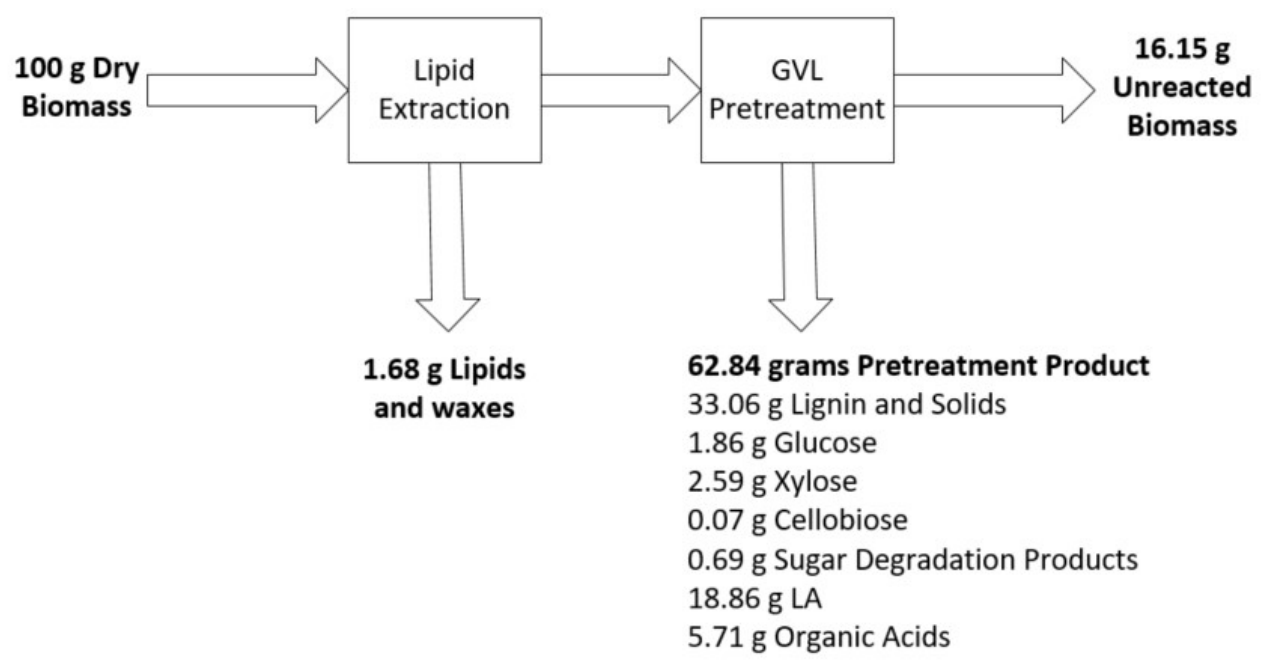

Total Mass Balance: $80.67 \mathrm{~g}$ recovered

Figure 3.7 Example mass balance of primary products flow chart for DEM sample 
Table 3.3 Lipid extraction and pretreatment mass balance averages with standard deviation for each extraction solvent. *Data unavailable; average based on two samples instead of three. **Data unavailable for two of the samples?; assumed that all three samples had the same unreacted biomass fraction.

\begin{tabular}{|c|c|c|c|c|c|c|c|c|c|}
\hline & \multicolumn{3}{|c|}{ Hexane } & \multicolumn{3}{|c|}{ МeTHF } & \multicolumn{3}{|c|}{ DEM } \\
\hline Lipids & 0.76 & \pm & 0.24 & 2.86 & \pm & 1.11 & 1.53 & \pm & 0.47 \\
\hline Lignin & 21.62 & \pm & 8.24 & 35.24 & \pm & 3.82 & 38.76 & \pm & 12.40 \\
\hline Glucose & 2.09 & \pm & 1.31 & 1.78 & \pm & 0.41 & 2.00 & \pm & 0.39 \\
\hline Cellobiose & 0.07 & \pm & 0.04 & 0.04 & \pm & 0.00 & 0.12 & \pm & 0.11 \\
\hline Xylose & 1.84 & \pm & 1.42 & 1.72 & \pm & 0.39 & 2.72 & \pm & 0.81 \\
\hline Furfural & 0.13 & \pm & 0.04 & 0.01 & \pm & 0.00 & $0.03 *$ & \pm & 0.02 \\
\hline 5-HMF & 0.14 & \pm & 0.12 & 0.61 & \pm & 0.47 & $0.73^{*}$ & \pm & 0.11 \\
\hline LA & 17.25 & \pm & 8.41 & 20.54 & \pm & 1.16 & 18.59 & \pm & 2.69 \\
\hline Formate & 2.34 & \pm & 0.87 & 1.47 & \pm & 0.40 & 9.90 & \pm & 16.10 \\
\hline Lactate & 0.44 & \pm & 0.20 & 0.40 & \pm & 0.26 & 0.99 & \pm & 0.16 \\
\hline Acetate & 4.70 & \pm & 2.45 & 7.07 & \pm & 4.30 & 4.12 & \pm & 0.95 \\
\hline $\begin{array}{l}\text { Unreacted } \\
\text { Biomass }\end{array}$ & 16.29 & \pm & 4.57 & $36.89^{* *}$ & \pm & 0.00 & 14.23 & \pm & 7.60 \\
\hline & 67.67 & & 12.37 & 108.64 & & 2.15 & 93.72 & & 12.25 \\
\hline
\end{tabular}




\section{Conclusions and Recommendations}

While MeTHF extracted the largest quantity of lipids, its quality was different than those extracted using hexane. The hexane extracts had the greatest number of wax compounds (C22-C30), with fewer compounds at lower carbon numbers. Therefore, it was determined that hexane produced the highest quality of waxes followed by DEM and then MeTHF. However, none of the solvents provided a pure wax, which would be a valueadded product. The lack of purity is likely because of the presence of intercellular components exposed from grinding the material prior to extraction.

While the amounts of glucose were comparable between solvents, DEM produced 33\% more xylose than hexane and its samples contained a significant amount of ethanol, most likely due to acid-catalyzed cleavage of residual DEM in the biomass during the GVL pretreatment. It also produced $118 \%$ more 5-hydroxymethylfurfural compared to the hexane samples. To determine the full effects of the DEM extraction, it would be helpful to complete the fermentation step and compare the ethanol yield to hexane. MeTHF did not significantly outperform hexane in sugar production and contained more 5-HMF.

This information is important to the scientific community because MeTHF and DEM are not suitable for extracting high quality waxes to serve as a value-added product. While the concept of a lipid extraction integration with a biorefinery may still be pursued, further research may look for alternate methods or solvents. The experiments conducted also demonstrated that the use of DEM in the reactor system may have an impact the amount of sugars produced and the ability of those sugars to be fermented.

Other methods for collecting waxes should be considered if the use of a similar process is still desired. It may be beneficial to explore extraction methods on whole portions of biomass either by dipping or washing in solvent or using mechanical methods as are used on carnauba plants ${ }^{21}$. Other methods used, such as for the candelilla plant, involved boiling the plant matter in a mildly acidic solution and collecting the waxes that float to the surface ${ }^{21}$. It may also be beneficial to conduct experiments with other green organic solvents.

It is also recommended that the lignin be further analyzed due to the noticeable physical difference in the lignin caused by the different pretreatment methods. There are opportunities to understand how the solvent extractions affected the quantity, quality, and pretreatment phase of the lignin extracted in this study.

Furthermore, a life cycle analysis should be conducted to determine if the green solvents discussed here, as well as any others considered in future experiments, to verify that the production and disposal of these green solvents are more sustainable than the use of hexane. This is important to consider so that solvents are chosen based on their overall environmental impact, and not only the production source. In addition to this, it is recommended that a full technoeconomic assessment be performed to evaluate the 
feasibility of building a full scale biorefinery with a lipid extraction preceding GVL pretreatment. 


\section{Reference List}

(1) Sharma, D.; Saini, A. Lignocellulosic Ethanol Production from a Biorefinery Perspective: Sustainable Valorization of Waste; Springer Singapore: Singapore, 2020. https://doi.org/10.1007/978-981-15-4573-3.

(2) Review of Fossil Fuels and Future Enrgies Technologies. 2015.

(3) Melillo, J.; Richmond, T.; Yohe, G. Climate Change Impacts in the United States: The Third National Climate Assessment; 2014.

(4) Kumar, P.; Sharma, P.; Sharma, P.; Sharma, D. Micro-Algal Lipids: A Potential Source of Biodiesel. J. Innov. Pharm. Biol. Sci. 2015, 2 (2), 135-143.

(5) Carriquiry, M.; Du, X.; Timilsina, G. Second Generation Biofuesls: Economics and Policies. Policy Res. Work. Pap. 2010, WPS5406.

(6) Motagamwala, A.; Won, W.; Maravelias, C.; Dumesic, J. An Engineered Solvent System for Sugar Production from Lignocellulosic Biomass Using Biomass Derived $\gamma$-Valerolactone. Green Chemsitry 2016, No. 21. https://doi.org/10.1039/C6GC02297A.

(7) De Bhowmick, G.; Sarmah, A. K.; Sen, R. Lignocellulosic Biorefinery as a Model for Sustainable Development of Biofuels and Value Added Products. Bioresour. Technol. 2018, 247, 1144-1154. https://doi.org/10.1016/j.biortech.2017.09.163.

(8) Extremophilic Microbial Processing of Lignocellulosic Feedstocks to Biofuels, Value-Added Products, and Usable Power; Sani, R. K., Krishnaraj Rathinam, N., Eds.; Springer International Publishing: Cham, 2018. https://doi.org/10.1007/9783-319-74459-9.

(9) Harron, A.; Powell, M.; Nunez, A.; Moreau, R. Analysis of Sorghum Wax and Carnauba Wax by Reversed Phase Liquid Chromatography Mass Spectrometry. Ind. Crops Prod. 2017, 98, 116-129.

(10) Cascant, M. M.; Breil, C.; Garrigues, S.; de la Guardia, M.; Fabiano-Tixier, A. S.; Chemat, F. A Green Analytical Chemistry Approach for Lipid Extraction: Computation Methods in the Selection of Green Solvents as Alternative to Hexane. Anal. Bioanal. Chem. 2017, 409 (14), 3527-3539. https://doi.org/10.1007/s00216017-0323-9.

(11) Luterbacher, J. S.; Rand, J. M.; Alonso, D. M.; Han, J.; Youngquist, J. T.; Maravelias, C. T.; Pfleger, B. F.; Dumesic, J. A. Nonenzymatic Sugar Production from Biomass Using Biomass-Derived -Valerolactone. Science 2014, 343 (6168), 277-280. https://doi.org/10.1126/science.1246748. 
(12) Meki, M.; Ogoshi, R.; Kiniry, J.; Crow, S.; Youkhana, A.; Nakahata, M.; Littlejohn, K. Performance Evaluation of Biomass Sorghum in Hawaii and Texas. Ind. Crops Prod. 2017, 103, 257-266.

(13) Dias, L. M.; Dos Santos, B. V.; Albuquerque, C. J. B.; Baeta, B. E. L.; Pasquini, D.; Baffi, M. A. Biomass Sorghum as a Novel Substrate in Solid-State Fermentation for the Production of Hemicellulases and Cellulases by Aspergillus Niger and A. Fumigatus. J. Appl. Microbiol. 2018, 124 (3), 708-718. https://doi.org/10.1111/jam.13672.

(14) Bergtold, J. S.; Shanoyan, A.; Fewell, J. E.; Williams, J. R. Annual Bioenergy Crops for Biofuels Production: Farmers' Contractual Preferences for Producing Sweet Sorghum. Energy 2017, 119, 724-731. https://doi.org/10.1016/j.energy.2016.11.032.

(15) Stefaniak, T. R.; Dahlberg, J. A.; Bean, B. W.; Dighe, N.; Wolfrum, E. J.; Rooney, W. L. Variation in Biomass Composition Components among Forage, Biomass, Sorghum-Sudangrass, and Sweet Sorghum Types. Crop Sci. 2012, 52 (4), 1949 1954. https://doi.org/10.2135/cropsci2011.10.0534.

(16) Billa, E.; Koullas, D. P.; Monties, B.; Koukios, E. G. Structure and Composition of Sweet Sorghum Stalk Components. Ind. Crops Prod. 1997, 6 (3), 297-302. https://doi.org/10.1016/S0926-6690(97)00031-9.

(17) Moreau, R. A.; Sharma, M. E.; Nuñez, A.; Mullen, C. A.; Powell, M. J.; Jones, K.; Harron, A.; Cafmeyer, J. T. Identification of Unique Aldehyde Dimers in Sorghum Wax Recovered after Fermentation in a Commercial Fuel Ethanol Plant. J. Am. Oil Chem. Soc. 2020, 97 (12), 1299-1308. https://doi.org/10.1002/aocs.12424.

(18) Hwang, K. T.; Cuppett, S. L.; Weller, C. L.; Hanna, M. A. Properties, Composition, and Analysis of Grain Sorghum Wax. J. Am. Oil Chem. Soc. 2002, 79 (6), 521-527. https://doi.org/10.1007/s11746-002-0515-5.

(19) Steinle, J. V. CARNAUBA WAX An Expedition to Its Source. Ind. Eng. Chem. 1936, 28 (9), 1004-1008. https://doi.org/10.1021/ie50321a003.

(20) de Freitas, C. A. S.; de Sousa, P. H. M.; Soares, D. J.; da Silva, J. Y. G.; Benjamin, S. R.; Guedes, M. I. F. Carnauba Wax Uses in Food - A Review. Food Chem. 2019, 291, 38-48. https://doi.org/10.1016/j.foodchem.2019.03.133.

(21) Eldridge, R. B. Ullman's Encyclopedia of Industrial Chemistry, 5th Completely Revised Edition Edited by Barbara Elvers, Stephen Hawkins, and William Russey. VCH: New York. 1995. \$14100 (36 Volume Set). ISBN 3-527-20126-2. J. Am. Chem. Soc. 1998, 120 (41), 10792-10792. https://doi.org/10.1021/ja9856203. 
(22) Vandenburg, L. E.; Wilder, E. A. The Structural Constituents of Carnauba Wax. J. Am. Oil Chem. Soc. 1970, 47 (12), 514-518. https://doi.org/10.1007/BF02639240.

(23) Nghiem, N. P.; O’Connor, J. P.; Hums, M. E. Integrated Process for Extraction of Wax as a Value-Added Co-Product and Improved Ethanol Production by Converting Both Starch and Cellulosic Components in Sorghum Grains. Fermentation 2018, 4 (1). http://dx.doi.org/10.3390/fermentation 4010012.

(24) Dalton, J. L.; Mitchell, H. L. Grain Wax Components, Fractionation of Sorghum Grain Wax. J. Agric. Food Chem. 1959, 7 (8), 570-573. https://doi.org/10.1021/jf60102a009.

(25) Anastas, P. T. Green Chemistry as Applied to Solvents. In Clean Solvents; ACS Symposium Series; American Chemical Society, 2002; Vol. 819, pp 1-9. https://doi.org/10.1021/bk-2002-0819.ch001.

(26) Pace, V.; Hoyos, P.; Castoldi, L.; Domínguez de María, P.; Alcántara, A. R. 2Methyltetrahydrofuran (2-MeTHF): A Biomass-Derived Solvent with Broad Application in Organic Chemistry. ChemSusChem 2012, 5 (8), 1369-1379. https://doi.org/10.1002/cssc.201100780.

(27) Alonso, D. M.; Wettstein, S. G.; Dumesic, J. A. Gamma-Valerolactone, a Sustainable Platform Molecule Derived from Lignocellulosic Biomass. Green Chem. 2013, 15 (3), 584-595. https://doi.org/10.1039/C3GC37065H.

(28) Tang, X.; Zeng, X.; Li, Z.; Hu, L.; Sun, Y.; Liu, S.; Lei, T.; Lin, L. Production of $\gamma$-Valerolactone from Lignocellulosic Biomass for Sustainable Fuels and Chemicals Supply. Renew. Sustain. Energy Rev. 2014, 40, 608-620. https://doi.org/10.1016/j.rser.2014.07.209.

(29) Girisuta, B.; Janssen, L. P. B. M.; Heeres, H. J. Green Chemicals: A Kinetic Study on the Conversion of Glucose to Levulinic Acid. Chem. Eng. Res. Des. 2006, 84 (5), 339-349. https://doi.org/10.1205/cherd05038.

(30) Date, N. S.; Hengne, A. M.; Huang, K.-W.; Chikate, R. C.; Rode, C. V. One Pot Hydrogenation of Furfural to 2-Methyl Tetrahydrofuran over Supported Monoand Bi-Metallic Catalysts. ChemistrySelect 2020, 5 (31), 9590-9600. https://doi.org/10.1002/slct.202002322.

(31) Zeng, J.; Wang, X.; Zhao, B.; Sun, J.; Wang, Y. Rapid In Situ Transesterification of Sunflower Oil. Ind. Eng. Chem. Res. 2009, 48 (2), 850-856. https://doi.org/10.1021/ie8008956.

(32) Sicaire, A.-G.; Vian, M. A.; Filly, A.; Li, Y.; Bily, A.; Chemat, F. 2Methyltetrahydrofuran: Main Properties, Production Processes, and Application in Extraction of Natural Products. In Alternative Solvents for Natural Products 
Extraction; Chemat, F., Vian, M. A., Eds.; Green Chemistry and Sustainable Technology; Springer: Berlin, Heidelberg, 2014; pp 253-268.

https://doi.org/10.1007/978-3-662-43628-8_12.

(33) de Jesus, S. S.; Ferreira, G. F.; Moreira, L. S.; Wolf Maciel, M. R.; Maciel Filho, R. Comparison of Several Methods for Effective Lipid Extraction from Wet Microalgae Using Green Solvents. Renew. Energy 2019, 143, 130-141. https://doi.org/10.1016/j.renene.2019.04.168.

(34) Applications of Diethoxymethane as a Versatile Process Solvent and Unique Reagent in Organic Synthesis | Organic Process Research \& Development https://pubs.acs.org/doi/abs/10.1021/op000288c (accessed 2021 -05 -13).

(35) Wolfe, G. M.; Kaiser, J.; Hanisco, T. F.; Keutsch, F. N.; de Gouw, J. A.; Gilman, J. B.; Graus, M.; Hatch, C. D.; Holloway, J.; Horowitz, L. W.; Lee, B. H.; Lerner, B. M.; Lopez-Hilifiker, F.; Mao, J.; Marvin, M. R.; Peischl, J.; Pollack, I. B.; Roberts, J. M.; Ryerson, T. B.; Thornton, J. A.; Veres, P. R.; Warneke, C. Formaldehyde Production from Isoprene Oxidation across $\mathrm{NO}_{x}$ Regimes. Atmospheric Chem. Phys. 2016, 16 (4), 2597-2610. https://doi.org/10.5194/acp-16-2597-2016.

(36) Use of Diethoxymethane as a Solvent for Phase Transfer-Catalyzed O-Alkylation of Phenols | Organic Process Research \& Development https://pubs.acs.org/doi/10.1021/op900324p (accessed 2021 -05 -13).

(37) Kumar, P.; Barrett, D.; Delwiche, M.; Stroeve, P. Methods for Pretreatment of Lignocellulosic Biomass for Efficient Hydrolysis and Biofuel Production | Industrial \& Engineering Chemistry Research. Ind. Eng. Chem. Res. 2009, 48, 3713-3729.

(38) Bajpai, P. Pretreatment of Lignocellulosic Biomass. In Pretreatment of Lignocellulosic Biomass for Biofuel Production; Bajpai, P., Ed.; SpringerBriefs in Molecular Science; Springer: Singapore, 2016; pp 17-70. https://doi.org/10.1007/978-981-10-0687-6_4.

(39) Trevorah, R. M.; Huynh, T.; Vancov, T.; Othman, M. Z. Bioethanol Potential of Eucalyptus Obliqua Sawdust Using Gamma-Valerolactone Fractionation. Bioresour. Technol. 2018, 250, 673-682. https://doi.org/10.1016/j.biortech.2017.11.084.

(40) Zhang, J.; Shen, W.; Collings, C.; Vander Meulen, K. A.; Fox, B. G.; Vázquez Ramos, L. M.; Dumesic, J. A.; Ding, S.-Y. Visualizing Plant Cell Wall Changes Proves the Superiority of Hydrochloric Acid over Sulfuric Acid Catalyzed $\gamma-$ Valerolactone Pretreatment. Chem. Eng. J. 2021, 412, 128660. https://doi.org/10.1016/j.cej.2021.128660. 
(41) Attard, T. M.; Bukhanko, N.; Eriksson, D.; Arshadi, M.; Geladi, P.; Bergsten, U.; Budarin, V. L.; Clark, J. H.; Hunt, A. J. Supercritical Extraction of Waxes and Lipids from Biomass: A Valuable First Step towards an Integrated Biorefinery. $J$. Clean. Prod. 2018, 177, 684-698. https://doi.org/10.1016/j.jclepro.2017.12.155.

(42) Attard, T. M.; McElroy, C. R.; Gammons, R. J.; Slattery, J. M.; Supanchaiyamat, N.; Kamei, C. L. A.; Dolstra, O.; Trindade, L. M.; Bruce, N. C.; McQueen-Mason, S. J.; Shimizu, S.; Hunt, A. J. Supercritical CO2 Extraction as an Effective Pretreatment Step for Wax Extraction in a Miscanthus Biorefinery. ACS Sustain. Chem. Eng. 2016, 4 (11), 5979-5988.

https://doi.org/10.1021/acssuschemeng.6b01220.

(43) Attard, T. M.; McElroy, C. R.; Hunt, A. J. Economic Assessment of Supercritical $\mathrm{CO} 2$ Extraction of Waxes as Part of a Maize Stover Biorefinery. Int. J. Mol. Sci. 2015, 16 (8), 17546-17564. http://dx.doi.org/10.3390/ijms160817546.

(44) L. Budarin, V.; S. Shuttleworth, P.; R. Dodson, J.; J. Hunt, A.; Lanigan, B.; Marriott, R.; J. Milkowski, K.; J. Wilson, A.; W. Breeden, S.; Fan, J.; K. Sin, E. H.; H. Clark, J. Use of Green Chemical Technologies in an Integrated Biorefinery. Energy Environ. Sci. 2011, 4 (2), 471-479. https://doi.org/10.1039/C0EE00184H.

(45) Scopel, E.; Santos, L. C. dos; Bofinger, M. R.; Martínez, J.; Rezende, C. A. Green Extractions to Obtain Value-Added Elephant Grass Co-Products in an Ethanol Biorefinery. J. Clean. Prod. 2020, 274, 122769. https://doi.org/10.1016/j.jclepro.2020.122769.

(46) National Weather Service: Wisconsin 30 year average temperature and precipitation 1981-2010.

(47) Sicaire, A.-G.; Vian, M.; Fine, F.; Joffre, F.; Carre, P.; Tostain, S.; Chemat, F. Alternative Bio-Based Solvents for Extraction of Fat and Oils: Solubility Prediction, Global Yield, Extraction Kinetics, Chemical Composition and Cost of Manufacturing. Int. J. Mol. Sci. 2015, 16 (4), 8430-8453. http://dx.doi.org/10.3390/ijms16048430.

(48) Zhang, Y.; Oates, L. G.; Link to external site, this link will open in a new window; Serate, J.; Xie, D.; Link to external site, this link will open in a new window; Pohlmann, E.; Bukhman, Y. V.; Karlen, S. D.; Young, M. K.; Higbee, A.; Link to external site, this link will open in a new window; Eilert, D.; Sanford, G. R.; Piotrowski, J. S.; Cavalier, D.; Ralph, J.; Coon, J. J.; Sato, T. K.; Link to external site, this link will open in a new window; Ong, R. G.; Link to external site, this link will open in a new window. Diverse Lignocellulosic Feedstocks Can Achieve High Field-scale Ethanol Yields While Providing Flexibility for the Biorefinery and Landscape-level Environmental Benefits. Glob. Change Biol. Bioenergy 2018, 10 (11), 825-840. http://dx.doi.org.services.lib.mtu.edu/10.1111/gcbb.12533. 
(49) Han, J.; Luterbacher, J. S.; Alonso, D. M.; Dumesic, J. A.; Maravelias, C. T. A Lignocellulosic Ethanol Strategy via Nonenzymatic Sugar Production: Process Synthesis and Analysis. Bioresour. Technol. 2015, 182, 258-266. https://doi.org/10.1016/j.biortech.2015.01.135. 